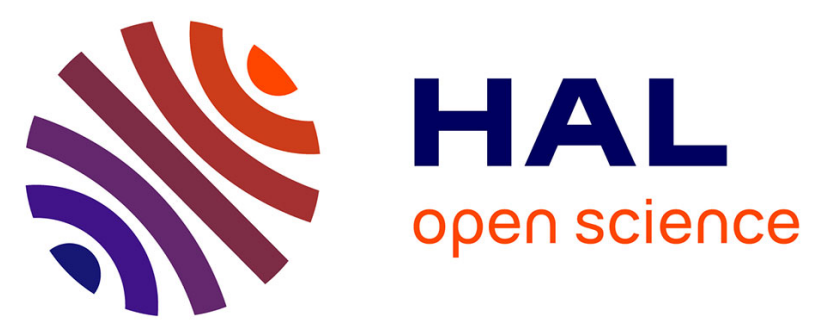

\title{
Impact of food consumption habits on the pesticide dietary intake: Comparison between a French vegetarian population and the general one.
}

Marieke van Audenhaege, Fanny Héraud, Céline Menard, Juliette Bouyrie, Sophie Morois, Gloria Calamassi-Tran, Sébastien Lesterle, Jean-Luc J.L.

Volatier, Jean-Charles Leblanc

\section{To cite this version:}

Marieke van Audenhaege, Fanny Héraud, Céline Menard, Juliette Bouyrie, Sophie Morois, et al.. Impact of food consumption habits on the pesticide dietary intake: Comparison between a French vegetarian population and the general one.. Food Additives and Contaminants, 2009, 26 (10), pp.13721388. 10.1080/02652030903031171. hal-00573899

\section{HAL Id: hal-00573899 https://hal.science/hal-00573899}

Submitted on 5 Mar 2011

HAL is a multi-disciplinary open access archive for the deposit and dissemination of scientific research documents, whether they are published or not. The documents may come from teaching and research institutions in France or abroad, or from public or private research centers.
L'archive ouverte pluridisciplinaire HAL, est destinée au dépôt et à la diffusion de documents scientifiques de niveau recherche, publiés ou non, émanant des établissements d'enseignement et de recherche français ou étrangers, des laboratoires publics ou privés. 


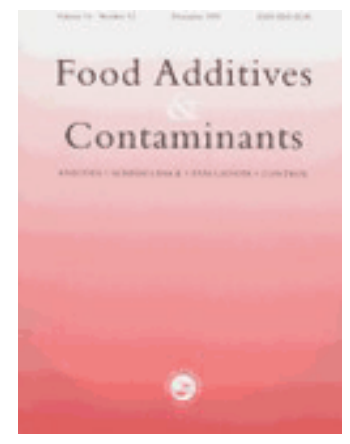

\section{Impact of food consumption habits on the pesticide dietary intake: Comparison between a French vegetarian population and the general one.}

\begin{tabular}{|r|l|}
\hline Journal: & Food Additives and Contaminants \\
\hline Manuscript ID: & TFAC-2009-014.R1 \\
\hline Manuscript Type: & Original Research Paper \\
\hline Author: & O7-May-2009 \\
\hline & $\begin{array}{l}\text { Complete List of Authors: } \\
\text { Van Audenhaege, Marieke; Agroparistech } \\
\text { Support to the Risk Assessment } \\
\text { Support to the Risk Assessment } \\
\text { Bouyrie, Juliette; Agroparistech } \\
\text { Morois, Sophie; Agroparistech } \\
\text { Calamassi-Tran, Gloria; French Food Safety Agency, Office of } \\
\text { Scientific Support to the Risk Assessment } \\
\text { Lesterle, Sébastien; French Food Safety Agency, Crops and } \\
\text { Environment Department } \\
\text { Volatier, Jean-Luc; French Food Safety Agency, Office of Scientific } \\
\text { Support to the Risk Assessment } \\
\text { Leblanc, Jean-Charles; French Food Safety Agency, Office of } \\
\text { Scientific Support to the Risk Assessment }\end{array}$ \\
\hline Methods/Techniques: & Exposure assessment \\
\hline Additives/Contaminants: & Pesticide residues \\
\hline Food Types: & \\
\hline &
\end{tabular}




\section{SCHOLARONE" \\ Manuscripts}




\section{Introduction}

Pesticide residues are regularly found in foodstuffs, as revealed by the European Commission which recently acknowledged that they were detected in $45.7 \%$ of the 62,569 samples analysed throughout the European Union in 2005 (European Commission, 2007). Pesticide residues are mainly present in cereals, vegetables and fruit. Thus, vegetables and fruit are found to contribute respectively to $75.8 \%$ and $20.5 \%$ of the estimated daily intakes of the Korean population (Chun and Kang, 2003). Some pesticides, mostly Persistent Organic Pollutants (POPs), also concentrate all along the food chain and contaminate foodstuffs of animal origin (IPCS, 1996). These commodities are found to be the main sources of organochlorine dietary exposure for the Australian population (Kannan et al., 1997) as well as for the Spanish one (Herrera et al., 1996).

Considering pesticide residues in foodstuffs as a public health issue, it is important to characterise which population is at risk. The pesticide dietary intake is a function of both residue levels in food and consumption habits. Vegetarians typically consume more fruit, vegetables and cereal products compared to individuals of the general population whose diet also includes animal-derived products. The aim of this study is to compare the impact of consumption habits of a French vegetarian population and the general one on their pesticide dietary intake.

\section{Material and methods}

\section{Consumption data}

French general population. Consumption data for the general population came from the

French individual consumption survey "enquête Individuelle et Nationale de Consommation Alimentaire" (INCA) conducted in 1999. The original sample of 1985 healthy adults (aged 15 
residence, agglomeration size) and the use of the quota method (age, gender, household size, individual occupation and socio-professional status) (Volatier, 2000). Subjects were asked to complete a seven-day food record diary (consecutive days) as well as other questionnaires on anthropometrical and socio-economic factors. Participants could estimate portion sizes through comparison of their actual consumption with photographs compiled in a manual adapted from the SuViMax picture booklet (Hercberg et al., 1994). Adult people identified as under-reporters by comparing their reported energy intake to their basal metabolic rate as estimated from the Schofield equations (Black, 2000) were excluded from the study. Thus, the final sample contained 1474 individuals.

The vegetarian population. Vegetarian subjects were recruited among adherents of the main French vegetarian or vegan societies between March and July 1997, through questionnaires published in the society's journal or directly distributed to the adherents (Leblanc et al., 2000). The total participation rate was $19.5 \%$ with 145 respondents. After deletion of incomplete questionnaires, consumption data of 137 individuals were available for analysis. For each participant, consumption data were collected in a 5-day food diary. Age, gender, weight and height were also listed. A classification of the vegetarian subjects was adopted on the basis of their effective food intakes (Table 1): 26 subjects considering themselves as vegetarians but having an omnivorous diet were gathered in the pseudo-vegetarian (OMN) group. The lacto-vegetarian (LV) group was composed of 41 subjects that only stand for dairy products in their diet. On the contrary, in the ovo-lacto-vegetarian (OLV) and pesco-lactovegetarian (PLV) groups - 43 and 16 adults - subjects get their proteins via both dairy products and respectively eggs or fish consumptions. At last, strict vegetarians, for whom all commodities of animal origin are excluded from the diet, were gathered in the vegan (VG) group (11 subjects). Although the number of subjects in each subgroup is rather low, the homogeneity of eating habits within each subgroup allows to consider it sufficient for further 
analysis (Leblanc, 2001). No adjustment was done according to the potential food consumption underreporting.

Residue data

Maximum Residue Limits (MRLs) and Acceptable Daily Intake (ADI). To assess the impact of consumption habits on the pesticide dietary intake, a fixed contamination level, set at the MRL, was considered whatever the population. Priority was given to MRLs in force within the European Union in July 2007, and next to French MRLs. Only substances, with an ADI and at least one MRL, were included in the study $(\mathrm{N}=421)$ (Table 2).

Sensitivity analysis on fish consumption habits. For a given pesticide, commodities with no existing MRL were not taken into account in the intake assessment. In particular, no MRL are actually defined at the European level for fish or fish-based products. However, several studies have already shown that they are potentially contaminated by pesticides, especially organochlorine compounds (Hites et al., 2004), and could even explain the presence of pesticides in human samples (Rivas et al., 2007). Moreover, PLV eat large amounts of fish as a source of proteins. A sensitivity analysis on fish consumption habits was consequently conducted on the Aldrin case. The total Aldrin intake was first calculated based on the contribution of all food items for which an MRL is defined. Then, it was compared to a total intake calculated considering a fictive maximum limit for the fish and fish-based products. This fictive value is assumed at the MRL defined for an other product of animal origin: meat. As Aldrin is a lipophilic compound, its MRL is defined on the fat, Thus, an average fat content of $10 \%$ was considered to define the fictive maximum limit for the fish and fish-based products $_{\mathbf{2}}$

Recipes

\section{Deleted: $\mathbb{1}$}

II

Deleted: of meat products

Deleted: express

Deleted: MRL

Deleted: on a total weight basis

Deleted: The fish residue level was set at the MRL defined for meat, corrected by an average meat fat content of $10 \%$ in order to get a residue level for the whole product. 
In order to match consumption data to MRLs, which are established on Raw Agricultural Commodities (RAC), the 895 food items defined in the INCA Survey and the 545 food items defined in the Vegetarian Consumption Survey were respectively broken down into 153 and 137 RAC. 402 standardized recipes, which have been defined taking account of industrial processes, home cooking habits and edible portions for the INCA Survey (Volatier, 2000), have been used. For the few vegetarian food items without any standardized recipe available, a recipe has been specifically defined according to the same approach than the one used to create the standardized recipes.

\section{Intake assessment}

The Theoretical Maximum Daily Intake (TMDI) (in mg. $\mathrm{kg}^{-1}$ bw. day ${ }^{-1}$ ) as defined by WHO (WHO, 1997) was estimated for each pesticide at the individual level, according to equation 1. The average was then derived for each population and expressed as a percentage of the ADI.

$$
\operatorname{TMDI}_{p, i}=\frac{\sum_{a \in A_{p}} \sum_{k=1}^{N i} C_{k, a, i} \times M R L_{p, a}}{N_{i} \times b w_{i}}
$$

Where:

TMDI $_{\mathrm{p}, \mathrm{i}}$ : Theoretical Maximum Daily Intake of the individual $i$ for the pesticide $p$, $\mathbf{C}_{\mathrm{k}, \mathrm{a}, \mathrm{i}}$ : quantity of foodstuff $a$ consumed by individual $i$ on day $k$, $\mathbf{A}_{\mathrm{p}}$ : list of foodstuffs for which a MRL is defined for the pesticide $p$, MRL $_{\mathrm{p}, \mathrm{a}}$ : Maximum Residue Limit for the pesticide $p$ in the foodstuff $a$, $\mathbf{N}_{\mathrm{i}}$ : number of days of consumption for the individual $i$, bw $_{\mathrm{i}}$ : body weight of individual $i$.

Deleted: and 254 recipes were respectively defined for the general and vegetarian populations in order to take account of industrial processes, home cooking habits and edible portions. 


\section{Statistical analysis}

The statistical analysis was conducted using the SAS@ software (SAS, Cary, NC 27513) running on the UNIX® system in order to characterize the determining factors of the total dietary intake and its differences among the studied populations.

First, the physiological characteristics (age and body mass index) were analysed in order to

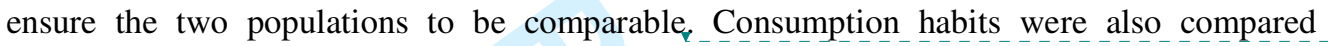
between the general population and the vegetarian cohort based on individual average intakes. As variables were not shown to have a Gaussian distribution according to the Shapiro-Wilk test, all comparisons between the general population and the vegetarian cohort were based on

\section{$\underline{\text { Kruskal-Wallis. }}$}

Into the vegetarian cohort, the five subgroups were considered to be independent due to the fact one individual can only belong to only one subgroup. As a Gaussian distribution was not assured within the studied subgroups, physiological comparisons were based on KruskalWallis tests. Similar tests were conducted to assess whether mean consumption levels were significantly different between two groups - for example the PLV group vs. the four other vegetarian subgroups.

Then, a specific analysis was done on few pesticides chosen according to their main contributors to the total dietary intake previously described by Menard et al. (2008):

- products of animal origin for Aldrin,

- fruit and vegetables for Diazinon, 
Carbamates_Aldicarb, Tri-allate, Propineb and Thiram) were also chosen for a rapid analysis (linear regression between subgroup average consumptions and TMDIs) because of total intakes differences between the population subgroups.

For Aldrin, Diazinon and Chlorpyrifos-methyl, the comparison was completed with multi linear regressions (ANOVA procedure) in order to explain the total dietary intake given by the TMDI/ADI ratio. The determining factors were consumptions levels of the different food groups, age, gender, Body Mass Index and pertinent interactions between those variables (for example BMI*gender).

\section{Results}

Description of the populations

Physiological characteristics of the studied populations. Characteristics of both populations are included in Table 1 according to diet group. The sex ratio (M/F) is similar between the studied populations ( 0.79 and 0.83 in the vegetarian and the general population respectively). Age distributions are relatively close in both populations with mean age of $49 \pm 15$ years for vegetarian population and $43 \pm 18$ for the general one (not significantly different).

The vegetarian population shows a lower mean BMI compared to the general population's one $\left(21.3 \pm 2.7 \mathrm{~kg} . \mathrm{m}^{-2}\right.$ vs. $23.5 \pm 3.8$, not significantly different). Indeed, respectively 74.5 and $64 \%$ of the vegetarian and the general populations have a BMI between 18.5 and 24.9. The vegetarian group includes less overweight or obese subjects (BMI higher than 25) than the general one (10.2\% vs. 30.6\%) and more thin subjects with BMI below 18.5 (15.3\% vs. $5.4 \%)$.

Some differences can also be observed among the subgroups. The mean age of the LV subgroup $(42.2 \pm 11.9$ years $)$ is significantly the lowest of the vegetarian subgroups $(\mathrm{p}=0,003)$ and especially when compared to the OMN subgroup $(56.6 \pm 19.4$ years, $\mathrm{p}=0.004)$. Women
Deleted: D

Deleted: these pesticides

Deleted: and

Deleted: population 
are dominant in all subgroups except in the $\mathrm{LV}(\mathrm{M} / \mathrm{F}$ ratio=1.21) and OLV $(\mathrm{M} / \mathrm{F}$ ratio=1.05) ones. The BMI of the PLV subgroup is shown to be significantly the lowest of the vegetarian subgroups $(\mathrm{p}=0.002)$, below the LV $(\mathrm{p}=0.004), \mathrm{OMN}(\mathrm{p}=0.012)$ and OLV $(\mathrm{p}=0.005)$ ones. Consumptions habits of the studied populations. As shown in Table 1, the total consumption, Deleted: 012 beverages excepted, is higher, but not significantly different, in the general population than in the vegetarian subgroups (1241.4 g. day ${ }^{-1}$ for the general population vs. $782.6-1174.2$ g.day ${ }^{-1}$ for the vegetarian subgroups), especially when it is compared to the PLV group in which subjects eat the least.

The general population consumes some products, which are hardly even eaten by vegetarians such as eggs $\left(\mathrm{p}<10^{-4}, 29.0\right.$ g. day ${ }^{-1}$ vs. $0.1-4.0$ g. day $\left.{ }^{-1}\right)$, dairy products $\left(\mathrm{p}<10^{-4}, 299.6\right.$ g. day ${ }^{1}$ vs. $2.9-119.4$ g. day $\left.{ }^{-1}\right)$ and other products of animal origin $\left(\mathrm{p}<10^{-4}, 161.2 \mathrm{~g}^{- \text {day }^{-1}}\right.$ for the general population vs. $1.5-9.0$ g. day ${ }^{-1}$ for the vegetarian subgroups). Vegetarians would also be more abstemious than subjects of the general population $\left(\mathrm{p}<10^{-4}\right)$ : their wine consumption goes from 42.6 to $105.2 \mathrm{~g}$. day $^{-1}$ while its reaches $160.3 \mathrm{~g}$. day ${ }^{-1}$ for the non vegetarian population.

On the contrary, compared to the general population, vegetarians eat more fruit $(247.7$ - 317.6 g. day $^{-1}$ for OLV, VG, LV and OMV groups, 124.7 g. day ${ }^{-1}$ for the PLV group vs. $173.4 \mathrm{~g}$. day $^{-1}$ for the general population), vegetables $\left(286.1-381.8\right.$ g. day ${ }^{-1} v s .170 .1$ g. day $\left.{ }^{-1}\right)$, cereals (189.9 and 206.3g. day ${ }^{-1}$ for PLV and LV groups, 128.7 - 157.3g. day ${ }^{-1}$ for VG, OLV and OMV groups vs. $173.0 \mathrm{~g}$. day ${ }^{-1}$ for the general population) and potatoes (53.3-86.9 g. day $^{-1}$ for VG, LV, OLV, 41.0 and 22.3 g. day ${ }^{-1}$ for OMV and PLV groups vs. $52.6 \mathrm{~g}$. day ${ }^{-1}$ for the general population) (figures not statistically different). Finally, consumption of other products

Deleted: oilseeds of plant origin would be similar between the general population $\left(22.3 \mathrm{~g}\right.$. day $\left.{ }^{-1}\right)$ and vegetarians groups $\left(18.8-36.3 \mathrm{~g}\right.$. day $\left.{ }^{-1}\right)$. 
The LV diet differs from the other vegetarian ones: fruit, vegetables and cereals are consumed

in the same amount while one or several foodstuffs are predominant in other diets. The OLV diet and the VG one (to a lower extent) distinguish themselves by a low cereal consumption (respectively 137.6 and 157.3 g. day ${ }^{-1}$ vs. $173.0-206.3$ g. day $^{-1}$ for the other vegetarian subgroups): meals are essentially composed of fruit and vegetables (respectively $62 \%$ and $64 \%$ of the total diet). The PLV diet is characterized by the opposite tendency: individuals of this subgroup have the highest cereal consumption $\left(206.3\right.$ g. day $^{-1}$ vs. $128.7-189.9$ g. day ${ }^{-1}$ for the other vegetarian subgroups) and the lowest fruit consumption among vegetarians (124.7 g. day ${ }^{-1}$ vs. $247.7-317.6$ g. day ${ }^{-1}$ for the other vegetarian subgroups).

Comparison of pesticide dietary intakes. Table 2 presents detailed results for pesticides with at least one TMDI above the ADI (detailed results for the other pesticides are provided in a supplemental material table).

Among the 421 pesticides taken into account, only 48 molecules (11.4\%) have a TMDI value above the ADI for at least one of the studied populations, half of them (23 molecules) representing a potential health risk in all subgroups. However, some differences exist between the two populations. The number of pesticides with TMDI above ADI is always higher in vegetarian subgroups (30 molecules for PLV, 41 for LV, 42 for OMN, 43 for VG and 44 for OLV) than in the general population (29 molecules). It should however be noticed that in terms of number of pesticides exceeding the ADI, the PLV group is extremely close to the general population (30vs. 29) and that other vegetarians groups are quite similar.

All the pesticides with TMDI higher than ADI for the general population have also at least one TMDI above ADI in one of the vegetarian subgroups. According to Table 2, most of the pesticides with TMDI above ADI are detected in all the vegetarian subgroups (25/48). Few pesticides have a TMDI higher than the ADI only for one of the vegetarian subgroups (5/48): 
Imazalil (VG), Formetanate hydrochlorid (OLV), Deltamethrin (PLV), Diquat (PLV) and Fenpropimorph (OLV). When pesticides are detected in three vegetarian subgroups $(5 / 48)$, it corresponds mostly to the [OMN, OLV, VG] subgroups (3/48) but also to the [LV, PLV, VG] and the [OMN, LV, OLV] ones (2/48). Finally, when pesticides are detected in four out of the five vegetarian subgroups (13/48), it always corresponds to the OMN, LV, OLV and VG subgroups.

ADI overruns are different from one pesticide class to another or even in the same class. The pesticides with TMDI above ADI are mainly organophosphates, organochlorine compounds and carbamates. All populations confounded, respectively $44 \%, 36 \%$ and $17 \%$ of the organophosphates, organochlorines and carbamates have a TMDI above ADI vs. 5\% for the other pesticides. The organochlorine and organophosphate classes appear with TMDI levels significantly higher in both the vegetarian $\left(\mathrm{p}=0.048\right.$ and $10^{-4}$ respectively) and the general ( $\mathrm{p}<10^{-4}$ and 0.001 respectively) populations than the other pesticides classes. Carbamates also appear with TMDI significantly higher than the other pesticides but only for the vegetarian population $(\mathrm{p}=0.007)$. In another hand, some pesticide classes would not present any longterm risk through dietary intake in both studied populations. For instance, the triazine and urea classes have no ADI exceedance. In the class of pyrethroïds, only Deltamethrin intakes are above ADI for the PLV subgroup (TMDI = 101.9\% ADI). Finally, only two molecules are potentially representing a risk in the azole class: Imazalil for the VG subgroup (TDMI = $102.5 \%$ ADI) and Prochloraz for all vegetarian subgroups except the PLV one (TMDI = 107.5 to $212.3 \%$ ADI).

\section{Determining factors of total pesticide intake}

Impact of the physiological characteristics. The impact of physiological characteristics of the populations has been analysed through multi-linear regression on few pesticides (Aldrin, 
Diazinon, Chlorpyrifos-methyl and several carbamates). The structure of the population in term of age or sex ratio is similar between the populations and did not have any significant effect on the total intake. Nevertheless, the interaction BMI*diet was found to explain the Chlorpyrifos-methyl intake variability $(\mathrm{p}<0.07)$ as well as the Aldrin intake one $(\mathrm{p}<0.07)$. A strong impact of fruit, vegetables and cereal consumptions on pesticide dietary intake. Results of the specific food contributions analyses reveal a strong correlation between the total dietary intake of carbamates and the consumption of plant origin foodstuffs for all vegetarian subgroups (Figures 1a \& 1b). By instance, TDMI is linear linked to the total average consumption of vegetables, fruit and wine for Tri-allate $\left(\mathrm{R}^{2}=0.99\right)$, Thiram $\left(\mathrm{R}^{2}=0.97\right)$ and Propineb $\left(\mathrm{R}^{2}=0.85\right)$ and to potato, vegetables and fruit consumption levels for Aldicarb $\left(\mathrm{R}^{2}=0.90\right)$. But food contributions are not the same between the different vegetarian groups. For Carbaryl, the intake of the PLV subgroup, whose TDMI is lower, mainly comes from cereals. On the contrary, individuals of the other groups, whose intake mainly results from the contribution of vegetables, are more exposed (Figure 1c). The same conclusion rises for Aldicarb: individuals of the PLV subgroup have lower intakes while their cereal consumption is the highest among vegetarian subgroups (TDMI $=97.6 \% \mathrm{ADI}$ vs. $123.2 \%$ to $174.5 \% \mathrm{ADI}$ ). Organophosphate intakes are also significantly different between the five vegetarian subgroups (respectively $\mathrm{p}=0.003$ and $\mathrm{p}=0.004$ for Chlorpyrifos-methyl and Diazinon). For Chlorpyrifos-methyl, cereals are major contributors to the dietary exposure (Figure 2) and PLV subjects are more exposed than the other groups. The classification order of vegetarian subgroups to Chlorpyrifos-methyl exposure is the same than for cereal consumption levels: $\mathrm{PLV}>\mathrm{LV}>\mathrm{VG}>\mathrm{OLV}>\mathrm{OMN}$ (Table 1). For Diazinon, for which vegetarians are more exposed than the general population (except PLV group), fruit are major contributors with respectively $54.2 \%, 58.7 \%, 63.7 \%, 67.9 \%$ and $69.7 \%$ of the Diazinon TMDI for the PLV, LV, OMN, OLV and VG subgroups (Figure 2). Therefore the OLV subgroup for which fruit
Deleted: and its interaction with the

Deleted: the interaction between BMI and the diet for
Deleted: vegetal

Deleted: - 
consumption level is the highest (Table 1 ) has the highest intake (TMDI $=130.4 \%$ ADI). On the contrary, subjects of the PLV subgroup for which fruit consumption level is the lowest (Table 1), are less exposed than subjects of the OMN ( $\mathrm{p}=0.002), \mathrm{LV}\left(\mathrm{p}<10^{-4}\right)$ and OLV $(\mathrm{p}=0.001)$ subgroups $(\mathrm{TMDI}=55.7 \%$ ADI $v s . \mathrm{TMDI}=103.7 \%, 115.1 \%$ and $130.4 \%$ ADI respectively).

The PLV diet: an apparent protection against organochlorines? The Aldrin dietary intake is higher in the general population than in the vegetarian cohort $(\mathrm{TMDI}=348.7 \%$ ADI $v s$. TMDI $=146.2$ to $183.9 \%$ ADI), mainly explained by the contribution of animal-origin commodities (respectively 59.5\% and 9.3\% TDMI for meat and dairy products) (Figure 2). PLV subjects were previously shown to be the least exposed subjects to Aldrin (Figure 2) but fish-derived products which represent a significant part of their diet were not taken into account in the assessment. When a fictive contamination is attributed to these foodstuffs, the order is reversed: subjects from the OMN, LV, OLV and VG groups become less exposed to Aldrin than PLV subjects (TMDI > 300\% ADI) (Figure 3).

\section{Discussion}

Formatted

48 out of the 421 pesticides included in the study may theoretically represent a long-term risk for the French general population or any of the 5 vegetarian subgroups due to the dietary intake. These molecules correspond mainly to the carbamate, organochlorine and organophosphate classes. On the contrary, most of pesticides belonging to the azole, pyrethroïd, triazine and urea classes have TMDIs below ADI. Vegetarians are critically exposed to a higher number of pesticides $(\mathrm{N}=48)$ than subjects of the general population $(\mathrm{N}$ =29). All the pesticides with TMDI above ADI for the general population would be detected as such in at least one vegetarian subgroup. 
Specific analysis about food contributions shows that fruit and vegetables consumption levels explain vegetarians overexposure to carbamates and Diazinon. The PLV subgroup, identified with a high cereal consumption level, has consequently higher TDMI for pesticides with cereals as main contributors, like Chlorpyriphos-methyl. On the contrary, vegetarians are less exposed to organochlorine compound like Aldrin, due to a lower consumption of animal origin commodities.

In order to eliminate any methodological bias in the comparison analysis, physiological characteristics of the two populations have first been compared. No significantly differences could be shown for sex ratio, age distributions and BMI. Moreover, consumption surveys used for this analysis are quite comparable. First, they have been conducted within the same timeframe, in the late 1990s. A new individual survey conducted among the French general population in 2006 - 2007 tends to show that consumption levels of fruit and vegetables haven't significantly changed since 1999 (Lafay, 2009). Thus the trends observed in this study should still be relevant. Secondly, both surveys are based on self-administered food diaries. Food diary allows to estimate a wide range of foods intake (Willet, 1998), which is adapted to this issue, as many food items may contain pesticides residues. Nevertheless, they can be associated with an alteration of the eating behaviour, conducting to a potential underestimation of real consumption level. They also require a high motivation from the subject which can lead to a poor response rate or a lowering quality of answers according to the days of inquiry (Willet, 1998). The food underreporting has been adjusted for subjects of the general population. It has not been the case for vegetarian ones, because of the low number of vegetarian subjects available for this analysis. This methodological bias may have minimized the differences of exposure between the two groups.

Nevertheless, dietary habits appear to be the main explanation to the observed differences. If amount levels of fruit, vegetables and cereals consumed are about equivalent for both subjects

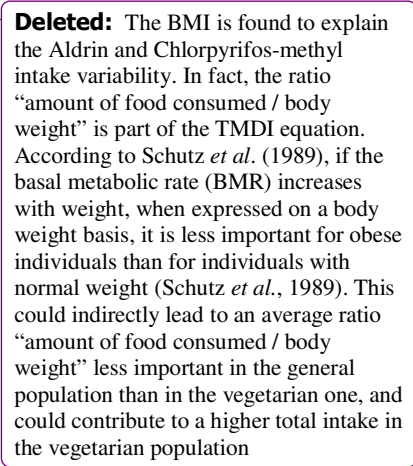


of the LV subgroup and the general population, one or several of these foodstuffs are predominant in the other vegetarian diets, in which foods of animal origin are limited or evicted. This "substitution" of animal commodities by plant origin ones impacts both the consumption and contamination parameters of the TDMI equation.

First, it increases the consumption level of plant origin products $\left(591.4 \mathrm{~g}\right.$. day $^{-1}$ for the general population $v s$. between 712.1 and 1037.1 g.day $^{-1}$-for the vegetarian subgroups), all the more that they are less energy-dense than animal origin foodstuffs so larger amounts are consequently needed to reach the same energy level.

Secondly, it impacts the contamination level as the MRL set for an animal origin product is replaced by a MRL set for a product of plant origin. But MRLs are not systematically defined for animal commodities. In fact, they are set only when feed may contain residues at a sufficiently high level $\left(>0.1 \mathrm{mg} . \mathrm{kg}^{-1}\right)$ and when metabolism studies show they may be found at levels higher than $0.1 \mathrm{mg} . \mathrm{kg}^{-1}$ in products of animal origin (European Commission, 2002). Moreover, except for pesticides also used as veterinary drugs or biocides, residues in food of animal origin result from an indirect usage via feed and water. Levels are consequently generally less important than for plant origin food on which the farmer may directly apply the pesticide. Exception can be underlined for lipophilic compounds such as for organochlorine and some organophosphate compounds, which tend to concentrate in animal commodities (IPCS, 1996). This explains why dietary intake is higher for the vegetarian population than for the general one, excepted for few compounds such as organochlorine ones.

The impact of the substitution is also observable between the different classes of plant origin commodities. For some pesticides, such as carbamates and Diazinon (organophosphate), intakes are mainly indicated by fruit and/or vegetables contributions. This explains why OLV and VG are more exposed than the other population subgroups. On the contrary, subjects of the PLV subgroup are less exposed to these compounds but more exposed to pesticides for 
which cereals are the main contributors (Pirimiphos-methyl, Malathion and Chlorpyrifosmethyl).

This substitution seems to have little impact on the total intake of some pesticides, such as Carbaryl. In fact, Carbaryl MRLs are set at $0.05 \mathrm{mg} . \mathrm{kg}^{-1}$ in meat, eggs, dairy products and most of vegetables and oil seeds, whereas it is 10 to 100 times higher than MRL set for cereals, wine, tomatoes and olives $\left(0.5-1,3,5\right.$ and $5 \mathrm{mg} . \mathrm{kg}^{-1}$ respectively). Some differences among the subgroups exposure are consequently expected. In fact, no clear effect of consumption habits on the residue intake can be shown. This could be explained by the fact that TMDI as expressed in this study depends not only on the residue intake but also on the ADI level. Indeed, it has previously been shown that when the ADI is very low, due to high toxicity of the pesticide, residue and consumption levels have a very limited impact on the TMDI (Menard et al., 2008). According to Table 2, it can be determined that the ADI for pesticides with TMDI > ADI for all population groups is of $0.004 \mathrm{mg} . \mathrm{kg} \mathrm{bw}^{-1}$. day ${ }^{-1}$ on average, 25 times lower than the average ADI $\left(0.09 \mathrm{mg} . \mathrm{kg} \mathrm{bw}^{-1}\right.$. day $\left.{ }^{-1}\right)$ based on pesticides with no ADI overrun.

Nevertheless, this study shows the importance in terms of risk assessment to take account of specific consumption habits among the population. Vegetarians actually represent $2 \%$ of the French population (Leblanc et al., 2000). Considering only the general population would potentially put vegetarians in situation of risk. This is all the more important that pesticide uses are sometimes limited on some specific food crops with high MRLs, such as cereals (Delthamethrin $3 \mathrm{mg} . \mathrm{kg}^{-1}$ ) or fruit (Imazalil $2 \mathrm{mg}$. $\mathrm{kg}^{-1}$ for citrus crop). Although the general population is protected from these two pesticides, the everyday high cereal consumers such as in the PLV group are theoretically overexposed to Delthametrin as well as the everyday high fruit consumers such as in the VG group for Imazalil. Considering that some ADI overruns would not be identified with a prediction model based only on the general population, it 
would be pertinent to develop new pesticide dietary intake model including vegetarian diets.

In that way, European Food Safety Authority has recently built a model for chronic and acute risk assessment at the European level, which includes a vegetarian population (from UK) (EFSA, 2007).

These conclusions need to be further investigated. In fact, it should be underlined that some foodstuffs, such as fish, are not taken into account in the risk assessment. This study aims to characterise this bias on the Aldrin case. The PLV group appears first to be more protected from Aldrin exposure than the other vegetarian subgroups. This is not any more the case when a theoretical fish contribution is taken into account. Dietary intakes of organochlorine compound and other lipophilic substances may have been consequently underestimated.

Secondly, the number of respondents standing between 11 and 43 does not allow robust comparisons between the vegetarian subgroups. Conclusions would need to be confirmed on more individuals.

Moreover, this analysis is based on the hypothesis that the food contamination level consumed by the general population and the vegetarian one are on average the same. However, some studies show that individuals with vegetarian habits would preferably buy organic or non-sprayed products (Leitzmann, 2003, Santucci, 2002, Schryver et al., 2007). These foods are supposed to be less contaminated than conventional products, even if no study has really proven it yet. Consequently, the higher consumption level of products potentially representing a risk could be offset by lower contamination levels. Further investigations based on the food supply habits of the population and the food contamination levels according to farming practices could be conducted in order to better characterise the sensitive population to be considered during pesticides residues risk assessment.

Finally, even if this study tends to show a higher risk of pesticides exposure for vegetarians, the vegetarian diet is generally associated with some beneficial effects. This diet would imply 
lower risk of ischemic diseases through its low rate in saturated fatty acids (Rajaram, 2003). A lower mortality rate for the vegetarian population has been also shown when compared to the general population (Key et al., 1999). Thus, further benefit-risk analysis of fruit and vegetables consumption aimed to balance the risk of pesticides exposure and nutritional beneficial effects could be conducted to handle the present issue in term of public health.

\section{Conclusion}

The goal of the present study was to understand how consumption habits, especially the vegetarian ones, can influence pesticide dietary intakes. The analysis of pesticide residue exposure was carried out via a maximalist approach, using MRL values as contamination levels of foodstuffs. Vegetarians were shown to be globally more exposed than the general population even if differences exist from one population subgroup to another and depending on the pesticide considered. The general population is exposed to higher levels than the vegetarian one for pesticides with animal products as main contributors (mainly organochlorines). On the contrary, pesticide dietary intakes coming from fruit, vegetables and cereals are higher in the vegetarian population. Finally, this analysis demonstrates that among the vegetarians included in the study, dietary intakes from plant origin foodstuffs (eaten in great quantities to comfort the absence of animal commodities such as meat, eggs and dairy products) largely offset the limited dietary intake associated to a negligible consumption of origin-animal commodities. The PLV diet is the only one that seems to be advantageous in terms of number of pesticides exceeding the ADI but the lack of MRL for fish certainly distorts the evaluation of pesticide intakes, particularly for residues that are persistent in the Deleted: dietary environment. Such results should however be considered cautiously because the approach using TMDI values is a very conservative one. Afterwards, it should be interesting to adopt a similar procedure using real food contamination levels instead of MRLs that represent 
theoretical estimations. Even if this study tends to show a higher risk for vegetarians concerning some pesticides, such a diet (even a lifestyle) could also presents great advantages for health. Thus it would be important to develop methodology in order to consider simultaneously benefits and risks associated with this particular diet.

\section{References}

Black AE. 2000. The sensitivity and specificity of the Goldberg cut-off for EI:BMR for identifying diet reports of poor validity. Eur J Clin Nutr. 54(5): 395-404.

Chun OK, Kang HG. 2003. Estimation of risks of pesticide exposure, by food intake, to Koreans. Food Chem Toxicol. 41(8): 1063-76.

EFSA. 2007. Reasoned Opinion on the potential chronic and acute risk to consumers' health arising from the proposed temporary EU MRLs according to Regulation EC No396/2005 on Maximum Residue Levels of Pesticides in Food and Feed of Plant and Animal Origin. Parma (IT): EFSA. Available from: http://www.efsa.europa.eu/EFSA/efsa_locale-1178620753816_1178620776373.htm.

European Commission. 2002. Guidelines Related to Setting Maximum Residue Limits. Appendix A, F, G, I and K. Brussels (BE): European Commission. Available from: http://ec.europa.eu/food/plant/protection/resources/publications_en.htm.

European Commission. 2007. Monitoring of pesticide residues in products of plant origin in the European Union, Norway, Iceland and Liechtenstein. Brussels: Available from:

Hercberg S, Deheeger M, Preziosi P. 1994. SU-VI-MAX. Portions alimentaires. Manuel photos pour l'estimation des quantités. Paris (FR): Editions Poly Technica.

Herrera A, Arino A, Conchello P, Lazaro R, Bayarri S, Perez-Arquillue C, Garrido MD, Jodral M, Pozo R. 1996. Estimates of mean daily intakes of persistent organochlorine pesticides from Spanish fatty foodstuffs. Bull Environ Contam Toxicol. 56(2): 173-7. 
Hites RA, Foran JA, Carpenter DO, Hamilton MC, Knuth BA, Schwager SJ. 2004. Global assessment of organic contaminants in farmed salmon. Science. 303(5655): 226-9.

IPCS. 1996. Persistent organic pollutants: an assessment report on DDT, aldrin, dieldrin, endrin, chlordane, heptachlor, hexachlorobenzene, mirex, toxaphene, polychlorinated biphenyls, dioxins and furans. Geneva: UNEP. Available from: http://www.chem.unep.ch/pops/ritter/en/ritteren.pdf.

Kannan K, Tanabe S, Giesy JP, Tatsukawa R. 1997. Organochlorine pesticides and polychlorinated biphenyls in foodstuffs from Asian and oceanic countries. Rev Environ Contam Toxicol. 152 :1-55.

Key TJ, Fraser GE, Thorogood M, Appleby PN, Beral V, Reeves G, Burr ML, Chang-Claude J, Frentzel-Beyme R, Kuzma JW, Mann J, McPherson K. 1999. Mortality in vegetarians and nonvegetarians: detailed findings from a collaborative analysis of 5 prospective studies. Am J Clin Nutr. 70(3 Suppl): 516S-524S.

Lafay L. 2009. Rapport de l'étude Individuelle Nationale des Consommations Alimentaires 2 (INCA 2) 2006/2007. Paris (FR) : Les rapports bleus de l'AFSSA.

Leblanc JC, Yoon H, Kombadjian A, Verger P. 2000. Nutritional intakes of vegetarian populations in France. Eur J Clin Nutr. 54(5): 443-9.

Leblanc JC. 2001. Influence de l'environnement sur le comportement alimentaire de groupes particuliers de consommateurs: Etude de l'équilibre nutritionnel et sanitaire des ingesta. Thèse pour l'obtention du diplôme de docteur de l'université Paris 7, spécialité : «Physiologie et Physiopathologie de la Nutrition». Soutenue le 1 juin $\underline{2001 .}$

Leitzmann C. 2003. Nutrition ecology: the contribution of vegetarian diets. Am J Clin Nutr. 78(3 Suppl): 657S-659S. 
Menard C, Heraud F, Nougadere A, Volatier JL, Leblanc JC. 2008. Relevance of integrating agricultural practices in pesticide dietary intake indicator. Food Chem Toxicol. 46(10): $3240-53$.

Rajaram S. 2003. The effect of vegetarian diet, plant foods, and phytochemicals on hemostasis and thrombosis. Am J Clin Nutr. 78(3 Suppl): 552S-558S.

Rivas A, Cerrillo I, Granada A, Mariscal-Arcas M, Olea-Serrano F. 2007. Pesticide exposure of two age groups of women and its relationship with their diet. Sci Total Environ. 382(1): 14-21.

Santucci F. 2002. Market issues in organic meat and dairy markets. Paper presented at: Symposium on organic markets for meat and dairy products: trade opportunities for developing countries. Nineteenth Session of the Intergovernmental group on meat and dairy products; 27 - 29 August 2002; Rome (IT).

Schryver T, Smith C, Wall M. 2007. Self-identities and BMI of Minnesotan soy consumers and non-consumers. Obesity (Silver Spring). 15(5): 1101-6.

Schutz Y, Flatt JP, Jequier E. 1989. Failure of dietary fat intake to promote fat oxidation: a factor favoring the development of obesity. Am J Clin Nutr. 50(2): 307-14.

Volatier J-L. 2000. Enquête INCA individuelle et nationale sur les consommations alimentaires. Paris (FR): Tech \& Doc.

WHO. 1997. Guidelines for predicting dietary intake of pesticides residues (revised). Prepared by the Global Environment Monitoring System - Food Contamination Monitoring and Assessment Programme (GEMS/Food) in collaboration with the Codex Committee on Pesticide Residues. Geneva $(\mathrm{CH})$ : WHO. Available from: http://www.who.int/foodsafety/chem/gems/en/index.html.

Willet W. 1998. Nutritional epidemiology. Monographs in Epidemiology and Biostatistics Volume 30. Oxfort (UK): Oxford University Press. 
Table 2. Detailed results concerning the 48 pesticides with at least one TMDI over ADI

\begin{tabular}{|c|c|c|c|c|c|c|c|c|c|}
\hline \multirow{2}{*}{$\begin{array}{c}\text { Active } \\
\text { substance }\end{array}$} & \multirow[b]{2}{*}{ Class } & \multirow{2}{*}{$\begin{array}{c}\text { ADI (source, } \\
\text { year) }\end{array}$} & \multirow{2}{*}{$\begin{array}{l}\text { MRL } \\
\text { reference }\end{array}$} & \multicolumn{6}{|c|}{ TMDI (\%ADI) } \\
\hline & & & & GP & OMN & LV & OLV & PLV & VG \\
\hline Imazalil & AZOL. & $0.025(\mathrm{a}, 1997)$ & $\mathrm{EU} / \mathrm{N}$ & 52,4 & 71,4 & 79,8 & 85,9 & 39,0 & 102,5 \\
\hline Prochloraz & AZOL. & $0.01(\mathrm{a}, 1988)$ & EU/N & 107,5 & 139,1 & 162,3 & 212,4 & 95,5 & 207,4 \\
\hline Aldicarb & CARB. & $0.001(a, 1994)$ & $\mathrm{EU} / \mathrm{N}$ & 105,9 & 123,2 & 145,1 & 148,3 & 97,6 & 174,5 \\
\hline Carbaryl & CARB. & $0.0008(\mathrm{a}, 2006)$ & $\mathrm{EU}$ & 876,9 & 858,1 & 1158,2 & 984,6 & 679,4 & 844,1 \\
\hline $\begin{array}{l}\text { Formetanate } \\
\text { hydrochlorid }\end{array}$ & CARB. & $0.004(\mathrm{a}, 2005)$ & $\mathrm{N}$ & 33,8 & 61,6 & 28,5 & 100,9 & 38,0 & 23,6 \\
\hline Propineb & CARB. & $0.007(\mathrm{a}, 2003)$ & $\mathrm{EU} / \mathrm{N}$ & 217,6 & 298,3 & 305,9 & 366,2 & 202,2 & 365,1 \\
\hline Thiram & CARB. & $0.01(\mathrm{a}, 2003)$ & $\mathrm{EU}$ & 177,3 & 290,5 & 258,1 & 347,4 & 201,1 & 362,7 \\
\hline Tri-allate & CARB. & $0.001(\mathrm{a}, 2003)$ & $\mathrm{EU} / \mathrm{N}$ & 74,5 & 114,4 & 110,2 & 133,4 & 102,3 & 143,2 \\
\hline Aldrin & $\mathrm{OC}$ & $0.0001(\mathrm{a},-)$ & $\mathrm{EU} / \mathrm{N}$ & 348,8 & 163,5 & 159,4 & 175,9 & 146,4 & 183,9 \\
\hline Dicofol & $\mathrm{OC}$ & $0.0025(\mathrm{a},-)$ & $\mathrm{EU} / \mathrm{N}$ & 165,1 & 146,4 & 172,4 & 187,0 & 60,0 & 139,8 \\
\hline Dieldrin & $\mathrm{OC}$ & $0.0001(\mathrm{a},-)$ & $\mathrm{EU} / \mathrm{N}$ & 348,8 & 163,5 & 159,4 & 175,9 & 146,4 & 183,9 \\
\hline Heptachlor & $\mathrm{OC}$ & $0.0001(\mathrm{a},-)$ & EU/N & 331,0 & 152,6 & 147,1 & 163,5 & 135,7 & 175,7 \\
\hline $\begin{array}{l}\text { Azinphos- } \\
\text { methyl }\end{array}$ & $\mathrm{OP}$ & $0.005(a, 1991)$ & $\mathrm{EU} / \mathrm{N}$ & 83,6 & 122,5 & 118,8 & 146,9 & 90,8 & 155,3 \\
\hline Chlorfenvinphos & $\mathrm{OP}$ & $0.0005(\mathrm{a},-)$ & EU & 95,0 & 192,0 & 140,8 & 176,9 & 198,8 & 259,2 \\
\hline $\begin{array}{l}\text { Chlorpyrifos- } \\
\text { methyl }\end{array}$ & $\mathrm{OP}$ & $0.01(\mathrm{a}, 1976)$ & $\mathrm{EU} / \mathrm{N}$ & 96,0 & 89.7 & 116,7 & 94.4 & 129,4 & 105,7 \\
\hline Diazinon & $\mathrm{OP}$ & $0.002(\mathrm{a}, 1999)$ & $\mathrm{EU} / \mathrm{N}$ & 75,4 & 103,7 & 115,1 & 130,4 & 55,7 & 120,0 \\
\hline Dichlorvos & $\mathrm{OP}$ & 8E-05 (a, 2005) & $\mathrm{EU} / \mathrm{N}$ & $\mathbf{7 3 5 5 , 9}$ & 6858,0 & 8901,7 & 7151,0 & 10729,6 & 8312,1 \\
\hline Dimethoate & $\mathrm{OP}$ & $0.001(\mathrm{a}, 2006)$ & $\mathrm{EU}$ & 92,9 & 100,5 & 114,7 & 120,6 & 87,2 & 143,0 \\
\hline Disulfoton & $\mathrm{OP}$ & $0.0003(\mathrm{a},-)$ & $\mathrm{EU} / \mathrm{N}$ & 168,8 & 151,0 & 156,3 & 155,0 & 134,1 & 152,6 \\
\hline Ethion & $\mathrm{OP}$ & $0.002(\mathrm{a},-)$ & $\mathrm{EU} / \mathrm{N}$ & 165,2 & 203,0 & 220,3 & 253,0 & 135,2 & 237,3 \\
\hline Malathion & $\mathrm{OP}$ & $0.03(\mathrm{a}, 2005)$ & $\mathrm{EU} / \mathrm{N}$ & 102,0 & 111,1 & 129,5 & 123,1 & 141,4 & 130,6 \\
\hline Methidathion & $\mathrm{OP}$ & $0.001(\mathrm{a},-)$ & EU/N & 187,3 & 200,1 & 252,2 & 303,2 & 89,2 & 258,8 \\
\hline Mevinphos & $\mathrm{OP}$ & $0.0008(\mathrm{a},-)$ & $\mathrm{EU} / \mathrm{N}$ & 134,0 & 233,4 & 211,7 & 279,2 & 182,5 & 303,3 \\
\hline Monocrotophos & $\mathrm{OP}$ & $0.0006(\mathrm{a},-)$ & $\mathrm{EU} / \mathrm{N}$ & 87,5 & 109,7 & 100,9 & 121,2 & 56,5 & 131,1 \\
\hline Naled & $\mathrm{OP}$ & $0.002(a, 2003)$ & $\mathrm{EU} / \mathrm{N}$ & 60,0 & 101,8 & 92,9 & 120,3 & 81,6 & 127,7 \\
\hline Omethoate & $\mathrm{OP}$ & $0.0004(\mathrm{~d},-)$ & $\mathrm{EU} / \mathrm{N}$ & 271,3 & 479,7 & 438,2 & 567,4 & 364,2 & 582,4 \\
\hline $\begin{array}{l}\text { Oxydemeton- } \\
\text { methyl }\end{array}$ & $\mathrm{OP}$ & 00003 (а 2006) & $\mathrm{EU} / \mathrm{N}$ & 1146 & 1146 & 159 & 132.1 & 12.1 & 1414 \\
\hline Phorate & $\mathrm{OP}$ & $0.0005(\mathrm{a}, 1999)$ & $\mathrm{EU} / \mathrm{N}$ & 131,2 & 144,5 & 146,4 & 162,5 & 134,6 & 175,2 \\
\hline Phosalone & $\mathrm{OP}$ & $0.01(\mathrm{a}, 1999)$ & $\mathrm{EU} / \mathrm{N}$ & 66,8 & 110,1 & 100,9 & 127,6 & 79,2 & 135,5 \\
\hline Phosmet & $\mathrm{OP}$ & $0.003(a, 2006)$ & $\mathrm{EU} / \mathrm{N}$ & 98,9 & 189,9 & 166,6 & 242,4 & 89,2 & 199,6 \\
\hline Phosphamidon & $\mathrm{OP}$ & $0.0005(\mathrm{a},-)$ & $\mathrm{EU} / \mathrm{N}$ & 206,5 & 327,8 & 309,7 & 383,5 & 283,7 & 409,9 \\
\hline $\begin{array}{l}\text { Pirimiphos- } \\
\text { methyl }\end{array}$ & $\mathrm{OP}$ & $0.004(a, 2005)$ & $\mathrm{EU} / \mathrm{N}$ & 429,6 & 397,7 & 499,8 & 426,3 & 556,5 & 454,6 \\
\hline Quinalphos & $\mathrm{OP}$ & $0.0005(\mathrm{c}, 1992)$ & $\mathrm{EU} / \mathrm{N}$ & 70,3 & 112,9 & 107,9 & 133,7 & 93,7 & 147,8 \\
\hline Sulfotep & $\mathrm{OP}$ & $0.0005(\mathrm{c}, 1995)$ & $\mathrm{N}$ & 231,1 & 393,5 & 350,3 & 466,0 & 281,9 & 488,9 \\
\hline Thiometon & $\mathrm{OP}$ & $0.003(\mathrm{a},-)$ & $\mathrm{N}$ & 97,0 & 154,0 & 145,3 & 189,1 & 123,2 & 194,8 \\
\hline Deltamethrin & PYR. & $0.01(\mathrm{a}, 2002)$ & $\mathrm{EU}$ & 73,4 & 67,0 & 85,4 & 72,0 & 101,9 & 83,6 \\
\hline Biphenyl & OTH. & $0.05(\mathrm{c}, 1989)$ & $\mathrm{N}$ & 138,4 & 134,7 & 172,6 & 234,0 & 56,6 & 157,0 \\
\hline Cyhexatin & OTH. & $0.0005(\mathrm{a}, 1987)$ & EU/N & 268,8 & 276,3 & 263,5 & 296,7 & 202,8 & 299,5 \\
\hline Diquat & ОТн. & $0.002(\mathrm{a}, 2001)$ & $\mathrm{EU} / \mathrm{N}$ & 54,1 & 53,3 & 62,0 & 65,7 & 109,0 & 75,7 \\
\hline Ethoxyquin & OTH. & $0.005(a, 1998)$ & $\mathrm{N}$ & 71,5 & 119,7 & 97,3 & 109,2 & 71,8 & 152,2 \\
\hline Fenpropimorph & OTH. & $0.003(a, 1999)$ & $\mathrm{EU} / \mathrm{N}$ & 70,4 & 83,1 & 91,3 & 108,6 & 61,6 & 99,8 \\
\hline Fentin acetate & OTH. & $0.0004(\mathrm{a},-)$ & $\mathrm{EU} / \mathrm{N}$ & 208,3 & 200,6 & 200,8 & 218,9 & 181,3 & 227,1 \\
\hline
\end{tabular}




\begin{tabular}{|c|c|c|c|c|c|c|c|c|c|}
\hline $\begin{array}{c}\text { Fentin } \\
\text { hydroxide }\end{array}$ & OTH. & $0.0004(\mathrm{a},-)$ & $\mathrm{EU} / \mathrm{N}$ & 208,3 & 200,6 & 200,8 & 218,9 & 181,3 & 227,1 \\
\hline $\begin{array}{l}\text { Hydrogen } \\
\text { cyanide }\end{array}$ & OTH. & $0.02(\mathrm{c}, 1993)$ & $\mathrm{EU} / \mathrm{N}$ & 198,2 & 167,7 & 232,3 & 169,4 & 291,3 & 201,5 \\
\hline Metaldehyde & OTH. & $0.025(\mathrm{a}, 2001)$ & $\mathrm{N}$ & 65,6 & 122,3 & 99,5 & 116,3 & 91,2 & 118,1 \\
\hline Ofurace & OTH. & 0.0007 (d, -) & $\mathrm{N}$ & 178,6 & 133,4 & 141,2 & 109,1 & 39,7 & 99,3 \\
\hline Rotenone & OTH. & $0.0001(\mathrm{a}, 2004)$ & $\mathrm{EU} / \mathrm{N}$ & 240,7 & 407,8 & 372,4 & 482,0 & 326,9 & 511,2 \\
\hline Vinclozolin & OTH. & $0.005(\mathrm{a}, 2004)$ & $\mathrm{EU} / \mathrm{N}$ & 184,2 & 266,4 & 216,9 & 358,9 & 171,0 & 293,1 \\
\hline
\end{tabular}

The abbreviations AZOL., CARB., OC, OP, PYR., TRIAZ., UREA and OTH. refer respectively to the following classes: azoles, carbamates, organochlorines, organophosphates, pyrethroïds, urea and other pesticides. ADI values are from Agritox database (http://www.dive.afssa.fr/agritox/php/donnees-essentielles.phpor), EFSA opinions (http://www.efsa.europa.eu/EFSA/efsa_locale-1178620753816_home.htm) or European directives (http://eur-lex.europa.eu/JOIndex.do?ihmlang=fr) (a), JMPR (http://www.codexalimentarius.net/mrls/pestdes/pest_ref/plst-f.htm) (b), Iris (http://cfpub.epa.gov/ncea/iris/index.cfm?fuseaction=iris.showSubstanceList) (c) and Australie (http://www.tga.gov.au/docs/pdf/adi.pdf) (d). No year is given for the ADI value if the pesticide is now forbidden. MRL values in force are national values (N) or European ones (EU). Pesticides potentially at risk for one group are highlighted in grey; TDMI values above ADI are in bold type. 
(a)

dietary intakes (\%ADI)

$400-y=0.4258 x+18.003$
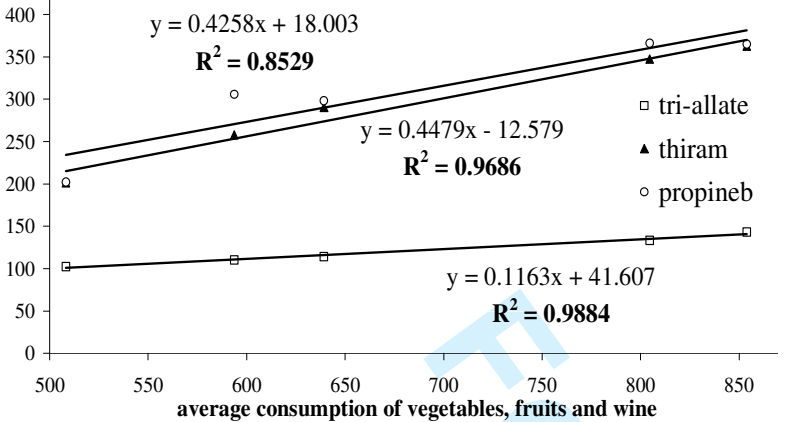

(c)

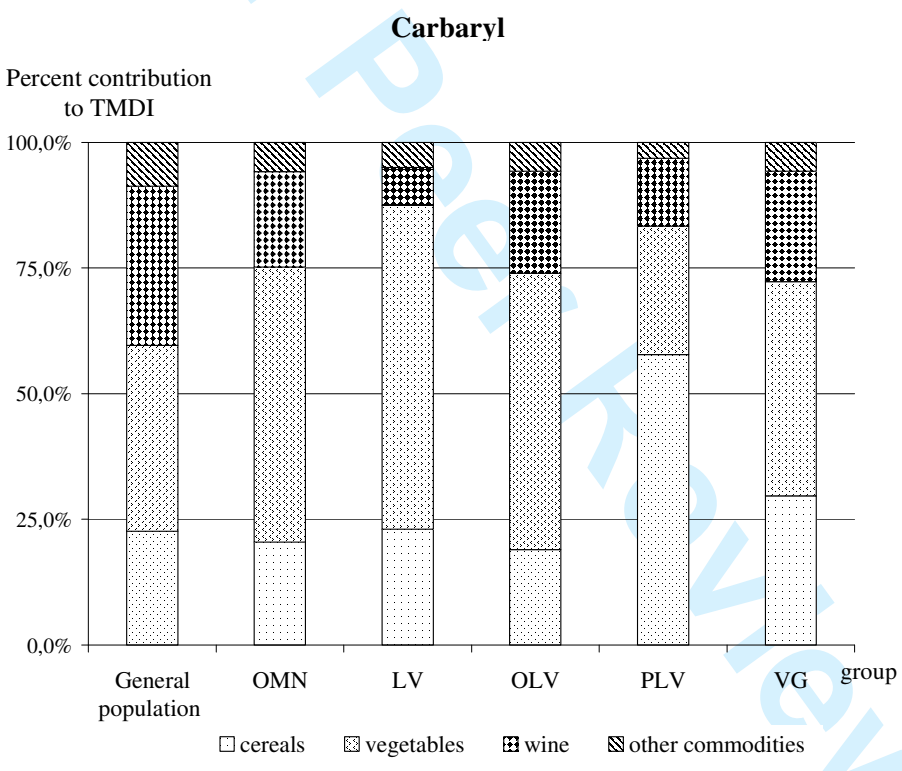

Estimations of TMDIs can be obtained from the average consumption of vegetal-origin products. (a) For Triallate, Thiram and Propineb, TDMI is a function of the average consumption of vegetables, fruit and wine in each vegetarian subgroup. (b) For Aldicarb, TDMI is a function of the average consumption of potatoes, vegetables and fruit in each vegetarian subgroup. (c) Contributions of vegetal-origin products to the Carbaryl dietary intake.

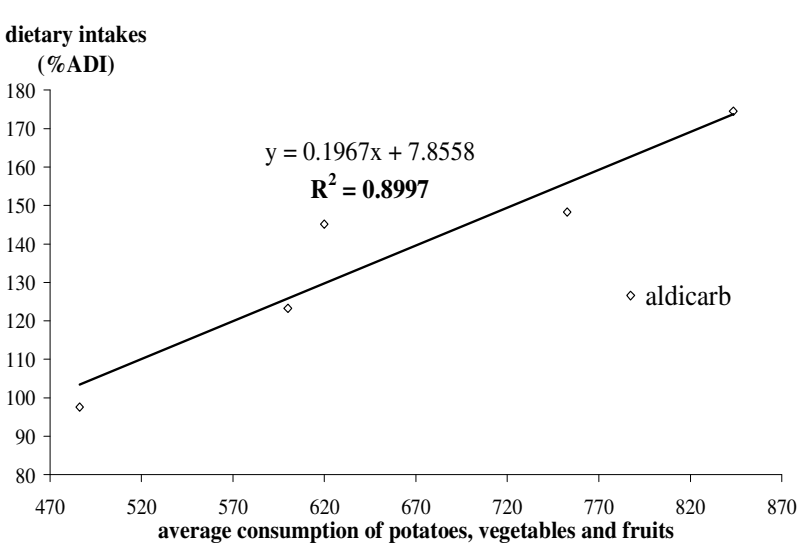


Figure 2. Contribution of foodstuffs to Aldrin (organochlorine), Chlorpyrifos-methyl and Diazinon (organophosphates) dietary intakes.

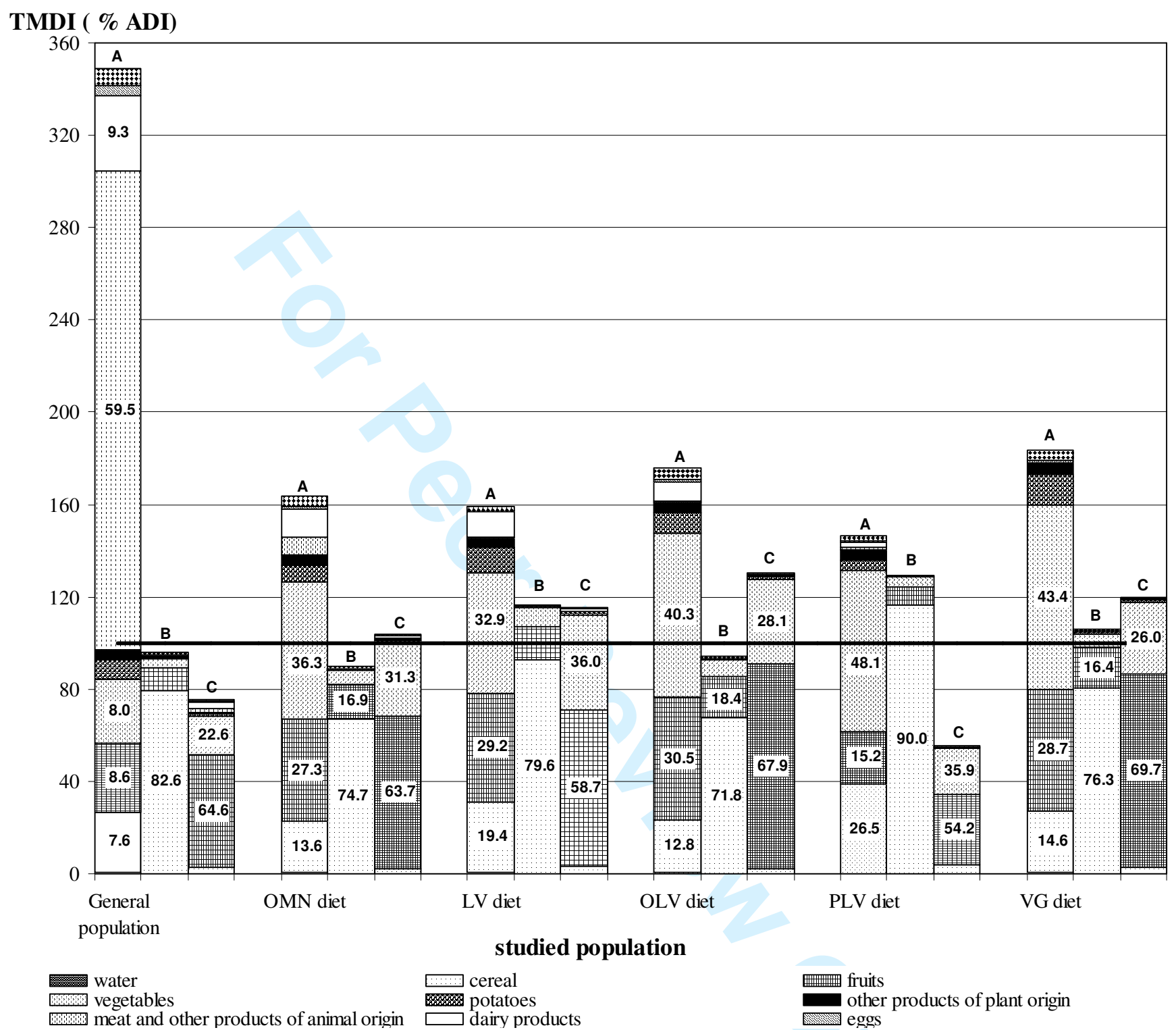


Figure 3. Impact of fish or fish-derived products consumption on the Adrin dietary intake.

\section{TMDI (\%ADI)}

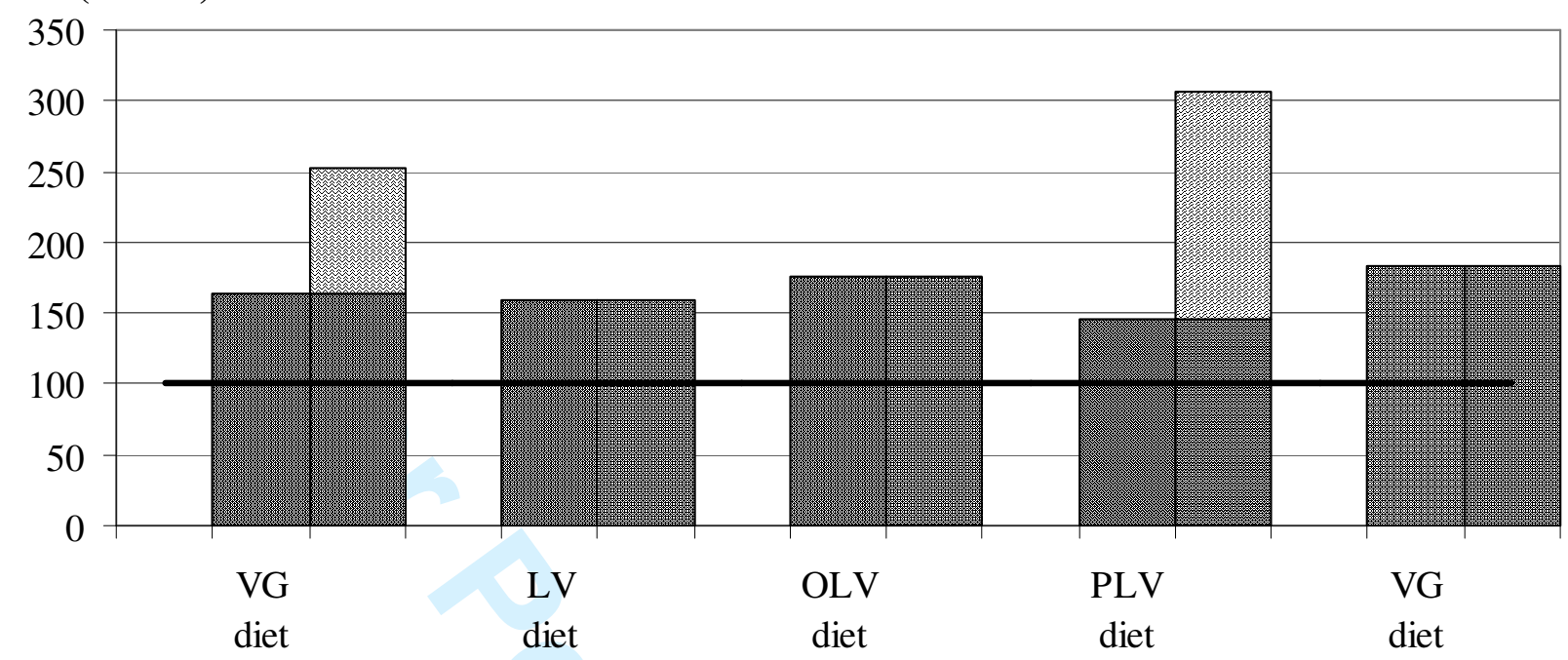

studied population

Other commodities $\quad$ Fish $\quad$ ADI 
Supplemental Table: Detailed results concerning the other pesticides studied

\begin{tabular}{|c|c|c|c|c|c|c|c|c|c|}
\hline \multirow{2}{*}{$\begin{array}{c}\text { Active } \\
\text { substance }\end{array}$} & \multirow[b]{2}{*}{ Class } & \multirow{2}{*}{$\begin{array}{l}\text { ADI (source, } \\
\text { year) }\end{array}$} & \multirow{2}{*}{$\begin{array}{c}\text { MRL } \\
\text { reference }\end{array}$} & \multicolumn{6}{|c|}{ TMDI (\%ADI) } \\
\hline & & & & GP & OMN & LV & OLV & PLV & VG \\
\hline $\begin{array}{c}\text { Amitrole } \\
\text { (Aminotriazole) }\end{array}$ & AZOL. & $0.001(\mathrm{a}, 2001)$ & EU & 10,0 & 14,1 & 14,6 & 16,4 & 14,2 & 18,7 \\
\hline Azaconazole & AZOL. & $0.025(\mathrm{~d},-)$ & $\mathrm{N}$ & 0,0 & 0,0 & 0,0 & 0,0 & 0,0 & 0,0 \\
\hline Benomyl & AZOL. & $0.1(\mathrm{a},-)$ & EU/N & 2,3 & 2,3 & 2,5 & 2,6 & 2,0 & 2,5 \\
\hline Bitertanol & AZOL. & $0.01(\mathrm{a}, 2004)$ & $\mathrm{EU} / \mathrm{N}$ & 47,0 & 76,0 & 86,5 & 89,0 & 40,6 & 88,1 \\
\hline Bromuconazole & AZOL. & $0.025(\mathrm{a}, 1999)$ & $\mathrm{N}$ & 0,7 & 0,8 & 0,9 & 0,9 & 0,7 & 1,0 \\
\hline $\begin{array}{l}\text { Carfentrazone- } \\
\text { ethyl }\end{array}$ & & & & & & & & & \\
\hline & AZOL. & $0.03(\mathrm{a}, 2003)$ & EU & 0,7 & 0,8 & 0,9 & 0,8 & 1,0 & 1,0 \\
\hline Chlorfenapyr & AZOL. & $0.02(\mathrm{~d},-)$ & $\mathrm{EU}$ & 2,5 & 3,5 & 3,6 & 4,0 & 3,5 & 4,5 \\
\hline Cyazofamid & AZOL. & $0.17(\mathrm{a}, 2003)$ & $\mathrm{EU}$ & 0,4 & 0,3 & 0,4 & 0,4 & 0,2 & 0,3 \\
\hline Cyproconazole & AZOL. & $0.01(\mathrm{a}, 1989)$ & $\mathrm{N}$ & 3,2 & 3,5 & 3,3 & 3,2 & 2,5 & 3,6 \\
\hline Difenoconazole & AZOL. & $0.01(\mathrm{a}, 1990)$ & $\mathrm{N}$ & 9,8 & 13,1 & 13,1 & 13,1 & 7,3 & 12,8 \\
\hline Diniconazole & AZOL. & $0.005(a, 1987)$ & $\mathrm{N}$ & 6,6 & 5,3 & 5,8 & 5,0 & 5,0 & 5,3 \\
\hline Epoxiconazole & AZOL. & $0.005(\mathrm{a}, 1992)$ & $\mathrm{N}$ & 2,3 & 1,8 & 2,1 & 1,7 & 1,7 & 1,6 \\
\hline Fenbuconazole & AZOL. & $0.036(a, 1999)$ & $\mathrm{N}$ & 1,8 & 2,0 & 2,5 & 2,1 & 1,0 & 1,6 \\
\hline Fipronil & AZOL. & $0.0002(a, 2003)$ & $\mathrm{N}$ & 16,5 & 16,5 & 21,3 & 18,2 & 21,8 & 20,4 \\
\hline Fluquinconazole & AZOL. & $0.003(\mathrm{a}, 1995)$ & $\mathrm{N}$ & 10,9 & 11,8 & 11,6 & 10,0 & 8,7 & 11,8 \\
\hline Flusilazole & AZOL. & $0.002(a, 2004)$ & $\mathrm{N}$ & 27,8 & 33,1 & 31,2 & 33,0 & 25,5 & 39,8 \\
\hline Flutriafol & AZOL. & $0.01(\mathrm{a}, 1987)$ & $\mathrm{N}$ & 2,8 & 2,5 & 3,3 & 2,7 & 4,5 & 3,2 \\
\hline Hexaconazole & AZOL. & $0.005(\mathrm{a}, 1989)$ & EU & 11,8 & 14,7 & 14,7 & 16,0 & 11,2 & 16,1 \\
\hline Metconazole & AZOL. & $0.01(\mathrm{a}, 2006)$ & $\mathrm{N}$ & 0,6 & 0,6 & 0,6 & 0,7 & 0,6 & 0,4 \\
\hline Myclobutanil & AZOL. & $0.02(a, 1989)$ & $\mathrm{EU} / \mathrm{N}$ & 23,3 & 29,2 & 32,2 & 40,4 & 12,7 & 37,4 \\
\hline Paclobutrazol & AZOL. & $0.1(\mathrm{a}, 1998)$ & $\mathrm{EU} / \mathrm{N}$ & 1,3 & 2,3 & 2,2 & 2,8 & 1,2 & 3,0 \\
\hline Penconazole & AZOL. & $0.03(\mathrm{a}, 1992)$ & $\mathrm{EU} / \mathrm{N}$ & 3,0 & 3,8 & 3,4 & 3,9 & 3,0 & 4,5 \\
\hline Propiconazole & AZOL. & $0.04(\mathrm{a}, 2003)$ & EU & 1,5 & 2,0 & 2,0 & 2,3 & 2,0 & 2,5 \\
\hline Tebuconazol & AZOL. & $0.03(\mathrm{a}, 1989)$ & $\mathrm{N}$ & 2,8 & 3,1 & 2,7 & 2,9 & 2,1 & 3,0 \\
\hline Tebufenpyrad & AZOL. & $0.01(\mathrm{a}, 1998)$ & $\mathrm{N}$ & 7,6 & 11,1 & 9,0 & 10,5 & 6,5 & 13,7 \\
\hline Tetraconazole & AZOL. & $0.008(a, 2006)$ & $\mathrm{N}$ & 7,0 & 9,4 & 7,5 & 8,6 & 5,5 & 11,2 \\
\hline Triadimefon & AZOL. & $0.03(\mathrm{a}, 1985)$ & $\mathrm{EU} / \mathrm{N}$ & 12,9 & 13,1 & 12,2 & 13,4 & 9,1 & 13,0 \\
\hline Triadimenol & AZOL. & $0.05(\mathrm{a}, 1989)$ & $\mathrm{EU} / \mathrm{N}$ & 7,7 & 7,9 & 7,3 & 8,0 & 5,5 & 7,8 \\
\hline Triazamate & AZOL. & $0.002(a, 1993)$ & $\mathrm{N}$ & 1,7 & 2,1 & 2,4 & 2,3 & 1,6 & 2,9 \\
\hline Triticonazole & AZOL. & $0.025(a, 2005)$ & $\mathrm{N}$ & 0,2 & 0,2 & 0,3 & 0,2 & 0,3 & 0,2 \\
\hline Asulam & CARB. & $0.05(\mathrm{c}, 1995)$ & $\mathrm{N}$ & 0,0 & 0,1 & 0,0 & 0,1 & 0,1 & 0,0 \\
\hline Benfuracarb & CARB. & $0.015(\mathrm{a}, 2002)$ & $\mathrm{EU} / \mathrm{N}$ & 8,5 & 5,3 & 5,2 & 5,7 & 4,6 & 5,8 \\
\hline Carbendazim & CARB. & $0.02(\mathrm{a}, 2005)$ & EU & 9,9 & 11,4 & 12,7 & 13,1 & 10,9 & 13,2 \\
\hline Carbofuran & CARB. & $0.002(a, 1999)$ & $\mathrm{EU} / \mathrm{N}$ & 54,5 & 36,6 & 38,8 & 42,1 & 22,2 & 32,9 \\
\hline Carbosulfan & CARB. & $0.01(\mathrm{a}, 1986)$ & $\mathrm{EU} / \mathrm{N}$ & 12,9 & 8,5 & 8,2 & 8,9 & 7,3 & 9,4 \\
\hline Chlorpropham & CARB. & $0.05(\mathrm{a}, 2003)$ & $\mathrm{EU} / \mathrm{N}$ & 10,9 & 9,2 & 13,0 & 10,7 & 5,0 & 15,0 \\
\hline Desmedipham & CARB. & $0.03(\mathrm{a}, 2004)$ & EU & 1,7 & 2,3 & 2,4 & 2,7 & 2,4 & 3,1 \\
\hline Diethofencarb & CARB. & $0.1(\mathrm{a}, 1991)$ & $\mathrm{N}$ & 0,9 & 1,1 & 1,4 & 1,7 & 0,6 & 1,1 \\
\hline Ethiofencarb & CARB. & $0.1(\mathrm{a},-)$ & $\mathrm{N}$ & 3,8 & 7,4 & 5,5 & 7,8 & 6,2 & 9,1 \\
\hline Fenoxycarb & CARB. & $0.05(\mathrm{a}, 1999)$ & $\mathrm{N}$ & 1,5 & 2,3 & 2,0 & 2,2 & 1,4 & 2,7 \\
\hline Furathiocarb & CARB. & $0.03(\mathrm{~d},-)$ & $\mathrm{EU} / \mathrm{N}$ & 4,3 & 2,7 & 2,7 & 2,9 & 2,4 & 3,0 \\
\hline Iprovalicarb & CARB. & $0.015(\mathrm{a}, 2002)$ & EU & 18,1 & 19,4 & 19,6 & 22,7 & 12,7 & 21,9 \\
\hline Mancozeb & CARB. & $0.05(\mathrm{a}, 1993)$ & $\mathrm{EU} / \mathrm{N}$ & 30,5 & 41,8 & 42,8 & 51,3 & 28,3 & 51,1 \\
\hline Maneb & CARB. & 0.05 (a, 2005) & $\mathrm{EU} / \mathrm{N}$ & 30,5 & 41,8 & 42,8 & 51,3 & 28,3 & 51,1 \\
\hline Methiocarb & CARB. & $0.013(\mathrm{a}, 2006)$ & $\mathrm{N}$ & 3,1 & 5,0 & 4,5 & 5,9 & 4,7 & 5,7 \\
\hline Methomyl & CARB. & $0.0025(\mathrm{a}, 2006)$ & $\mathrm{EU} / \mathrm{N}$ & 76,8 & 81,7 & 81,9 & 99,9 & 56,5 & 93,5 \\
\hline Metiram & CARB. & $0.03(\mathrm{a}, 1993)$ & $\mathrm{EU} / \mathrm{N}$ & 50,8 & 69,6 & 71,4 & 85,5 & 47,2 & 85,2 \\
\hline
\end{tabular}




\begin{tabular}{|c|c|c|c|c|c|c|c|c|c|}
\hline Molinate & CARB. & $0.008(\mathrm{a}, 2003)$ & EU & 6,1 & 8,5 & 8,7 & 9,9 & 8,3 & 11,2 \\
\hline Oxamyl & CARB. & $0.001(\mathrm{a}, 2005)$ & EU & 10,7 & 14,7 & 15,9 & 17,4 & 14,3 & 18,5 \\
\hline Phenmediphame & CARB. & $0.03(\mathrm{a}, 2004)$ & EU & 3,0 & 3,3 & 3,0 & 3,4 & 2,7 & 3,5 \\
\hline Pirimicarbe & CARB. & $0.035(a, 2003)$ & EU/N & 8,9 & 14,8 & 13,6 & 17,5 & 11,9 & 18,5 \\
\hline $\begin{array}{l}\text { Propamocarbe } \\
\text { chlorhydrate }\end{array}$ & CARB. & $0.29(\mathrm{a}, 2006)$ & $\mathrm{N}$ & 0,8 & 1,4 & 1,3 & 2,4 & 1,3 & 2,4 \\
\hline Propham & CARB. & $0.02(\mathrm{c}, 1987)$ & $\mathrm{EU} / \mathrm{N}$ & 4,1 & 3,9 & 3,9 & 4,3 & 3,4 & 4,4 \\
\hline Propoxur & CARB. & $0.02(\mathrm{a},-)$ & $\mathrm{EU} / \mathrm{N}$ & 5,2 & 5,7 & 5,4 & 6,2 & 5,8 & 6,3 \\
\hline Prosulfocarbe & CARB. & $0.005(\mathrm{a}, 2005)$ & $\mathrm{N}$ & 1,2 & 1,0 & 1,3 & 1,0 & 0,9 & 1,2 \\
\hline Thiabendazole & CARB. & $0.1(\mathrm{a}, 2001)$ & $\mathrm{EU} / \mathrm{N}$ & 22,5 & 30,3 & 33,7 & 37,2 & 16,1 & 49,7 \\
\hline Thiodicarb & CARB. & $0.01(\mathrm{a}, 2005)$ & EU & 19,2 & 20,4 & 20,5 & 25,0 & 14,1 & 23,4 \\
\hline $\begin{array}{c}\text { Thiophanate- } \\
\text { methyl }\end{array}$ & CARB. & $0.08(\mathrm{a}, 1998)$ & EU & 6,1 & 6,4 & 6,6 & 7,1 & 4,0 & 6,2 \\
\hline Zineb & CARB. & $0.03(\mathrm{a},-)$ & EU/N & 1,4 & 69,6 & 71,4 & 85,5 & 47,2 & 85,2 \\
\hline $\begin{array}{c}\text { No ADI } \\
\text { available }\end{array}$ & CARB. & \multicolumn{8}{|c|}{ Barban, Chlorbufam, Di-allate } \\
\hline Chlordane & OC & $0.0005(\mathrm{a},-)$ & $\mathrm{EU} / \mathrm{N}$ & 38,5 & 33,8 & 35,7 & 37,5 & 36,5 & 41,9 \\
\hline Chlorothalonil & $\mathrm{OC}$ & $0.015(\mathrm{a}, 2003)$ & $\mathrm{EU} / \mathrm{N}$ & 52,4 & 74,0 & 61,5 & 77,1 & 55,2 & 71,7 \\
\hline DDT & OC & $0.01(\mathrm{a},-)$ & $\mathrm{EU} / \mathrm{N}$ & 17,5 & 8,0 & 7,7 & 8,4 & 6,8 & 8,8 \\
\hline Endosulfan & OC & $0.006(a, 1998)$ & $\mathrm{EU} / \mathrm{N}$ & 27,1 & 28,6 & 32,8 & 36,1 & 17,3 & 31,7 \\
\hline Endrin & OC & $0.0002(\mathrm{a},-)$ & $\mathrm{EU} / \mathrm{N}$ & 77,7 & 70,0 & 70,8 & 79,5 & 67,0 & 87,9 \\
\hline Lindane & OC & $0.005(\mathrm{a},-)$ & $\mathrm{EU} / \mathrm{N}$ & 4,2 & 3,0 & 2,9 & 3,3 & 2,7 & 3,5 \\
\hline Methoxychlor & $\mathrm{OC}$ & $0.1(\mathrm{a},-)$ & $\mathrm{EU} / \mathrm{N}$ & 0,1 & 0,1 & 0,1 & 0,2 & 0,1 & 0,2 \\
\hline $\begin{array}{c}\text { No ADI } \\
\text { available }\end{array}$ & $\mathrm{OC}$ & \multicolumn{8}{|c|}{ Alpha-BHC, BHC (beta isomer), Camphechlor, $\mathrm{HCH}$, Hexachlorobenzene } \\
\hline Acephate & $\mathrm{OP}$ & $0.03(\mathrm{a},-)$ & $\mathrm{EU}$ & 1,1 & 1,1 & 1,1 & 1,2 & 1,0 & 1,2 \\
\hline Azinphos-ethyl & $\mathrm{OP}$ & $0.002(\mathrm{~d},-)$ & EU & 17,1 & 18,1 & 19,6 & 19,9 & 19,4 & 21,9 \\
\hline Bromophos & $\mathrm{OP}$ & $0.04(\mathrm{a},-)$ & $\mathrm{N}$ & 15,0 & 25,4 & 23,2 & 30,1 & 20,4 & 31,9 \\
\hline $\begin{array}{l}\text { Bromophos- } \\
\text { ethyl }\end{array}$ & OP & $0.003(\mathrm{a},-)$ & $\mathrm{EU} / \mathrm{N}$ & 11,7 & 18,8 & 18,0 & 22,3 & 15,6 & 24,6 \\
\hline $\begin{array}{l}\text { Chlorpyrifos- } \\
\text { ethyl }\end{array}$ & OP & $0.01(\mathrm{a}, 2005)$ & EU & 25,7 & 39,7 & 44,5 & 57,8 & 21,1 & 52,9 \\
\hline Dioxathion & OP & $0.0015(\mathrm{a},-)$ & $\mathrm{EU} / \mathrm{N}$ & 23,4 & 37,6 & 36,0 & 44,6 & 31,2 & 49,3 \\
\hline Ethephon & $\mathrm{OP}$ & $0.03(\mathrm{a}, 2005)$ & $\mathrm{EU} / \mathrm{N}$ & 9,9 & 11,7 & 13,4 & 12,2 & 7,2 & 12,0 \\
\hline Ethoprophos & $\mathrm{OP}$ & $0.0004(\mathrm{a}, 1999)$ & $\mathrm{N}$ & 9,6 & 14,2 & 14,2 & 17,5 & 11,5 & 18,8 \\
\hline Etrimfos & $\mathrm{OP}$ & $0.003(\mathrm{a},-)$ & $\mathrm{N}$ & 4,5 & 3,9 & 3,5 & 3,2 & 2,5 & 3,9 \\
\hline Fenamiphos & $\mathrm{OP}$ & $0.0008(\mathrm{a}, 1999)$ & $\mathrm{EU} / \mathrm{N}$ & 34,7 & 44,5 & 47,3 & 51,7 & 41,0 & 54,4 \\
\hline Fenitrothion & $\mathrm{OP}$ & $0.005(a, 2006)$ & $\mathrm{EU}$ & 8,3 & 6,3 & 4,3 & 7,6 & 4,2 & 7,6 \\
\hline Fenthion & OP & $0.007(\mathrm{a}, 1997)$ & EU/N & 35,9 & 39,7 & 49,8 & 58,8 & 14,1 & 47,1 \\
\hline Fonofos & $\mathrm{OP}$ & $0.002(\mathrm{c}, 1991)$ & $\mathrm{N}$ & 5,9 & 28,8 & 16,8 & 22,4 & 24,9 & 31,3 \\
\hline Fosthiazate & OP & $0.004(\mathrm{a}, 2003)$ & $\mathrm{EU}$ & 5,2 & 7,3 & 7,6 & 8,7 & 7,4 & 10,0 \\
\hline Isofenphos & OP & $0.001(\mathrm{a},-)$ & $\mathrm{N}$ & 8,6 & 13,6 & 13,7 & 17,1 & 9,6 & 17,7 \\
\hline Mecarbam & OP & $0.002(\mathrm{a},-)$ & $\mathrm{EU} / \mathrm{N}$ & 24,2 & 33,8 & 34,7 & 39,1 & 33,1 & 43,7 \\
\hline Methacrifos & OP & $0.006(\mathrm{a},-)$ & EU/N & 9,2 & 11,6 & 11,9 & 13,3 & 11,1 & 14,6 \\
\hline Methamidophos & $\mathrm{OP}$ & $0.001(\mathrm{a}, 2005)$ & $\mathrm{EU} / \mathrm{N}$ & 30,4 & 35,6 & 29,2 & 30,3 & 32,4 & 28,5 \\
\hline Parathion & $\mathrm{OP}$ & $0.004(\mathrm{a},-)$ & EU/N & 20,5 & 19,6 & 19,6 & 21,3 & 17,1 & 21,9 \\
\hline $\begin{array}{l}\text { Parathion- } \\
\text { methyl }\end{array}$ & OP & $0.003(\mathrm{a},-)$ & EU/N & 46,4 & 70,7 & 64,6 & 82,9 & 54,4 & 87,2 \\
\hline Phoxim & $\mathrm{OP}$ & $0.004(\mathrm{a},-)$ & $\mathrm{EU} / \mathrm{N}$ & 6,6 & 5,6 & 7,8 & 6,1 & 9,7 & 6,7 \\
\hline Pirimiphos ethyl & OP & $0.0002(\mathrm{~d},-)$ & $\mathrm{N}$ & 30,6 & 51,4 & 47,0 & 60,8 & 41,2 & 64,3 \\
\hline Profenofos & OP & $0.01(\mathrm{a},-)$ & $\mathrm{EU} / \mathrm{N}$ & 6,0 & 7,0 & 7,1 & 8,0 & 6,7 & 8,7 \\
\hline Pyrazophos & OP & $0.004(\mathrm{a},-)$ & $\mathrm{EU} / \mathrm{N}$ & 15,9 & 18,1 & 18,3 & 20,4 & 16,8 & 21,9 \\
\hline Terbufos & OP & $0.0002(\mathrm{a}, 1999)$ & $\mathrm{N}$ & 9,2 & 19,1 & 18,0 & 22,4 & 22,9 & 27,3 \\
\hline
\end{tabular}


Tetrachlor-

\begin{tabular}{cccccccccc} 
vinphos & OP & $0.05(\mathrm{~d},-)$ & $\mathrm{N}$ & 15,5 & 24,6 & 22,7 & 30,0 & 14,5 & 31,3 \\
Triazophos & OP & $0.001(\mathrm{a},-)$ & EU & 19,2 & 18,1 & 19,0 & 19,6 & 17,7 & 20,6 \\
Trichlorfon & OP & $0.01(\mathrm{a}, 1978)$ & EU & 31,0 & 49,6 & 45,4 & 59,1 & 37,0 & 62,4 \\
Vamidothion & OP & $0.008(\mathrm{a},-)$ & EU/N & 8,9 & 16,7 & 14,3 & 17,5 & 11,8 & 22,3 \\
\hline
\end{tabular}

No ADI OP

\begin{tabular}{|c|c|c|c|c|c|c|c|c|c|}
\hline \multirow{2}{*}{$\begin{array}{c}\text { available } \\
\text { Acrinathrin }\end{array}$} & \multicolumn{9}{|c|}{ Chlormephos, Ditalimfos, Fenchlorphos, Formothion, Heptenophos, Pyridiphenthion, TEPP } \\
\hline & PYR. & $0.02(\mathrm{a}, 1990)$ & $\mathrm{N}$ & 1,4 & 1,9 & 2,3 & 2,1 & 0,7 & 1,6 \\
\hline Alphamethrin & PYR. & $0.015(\mathrm{a}, 2004)$ & $\mathrm{EU} / \mathrm{N}$ & 28,2 & 48,1 & 43,7 & 55,4 & 29,9 & 55,2 \\
\hline \multirow{2}{*}{$\begin{array}{l}\text { Beta-Cyfluthrin } \\
\text { Bifenthrin }\end{array}$} & PYR. & $0.003(\mathrm{a}, 2002)$ & $\mathrm{EU} / \mathrm{N}$ & 26,9 & 30,2 & 27,6 & 38,0 & 24,5 & 39,0 \\
\hline & PYR. & $0.015(\mathrm{a}, 2005)$ & $\mathrm{EU} / \mathrm{N}$ & 18,0 & 24,0 & 22,8 & 30,4 & 21,2 & 33,4 \\
\hline Bioresmethrin & PYR. & $0.03(\mathrm{a},-)$ & $\mathrm{N}$ & 0,6 & 0,9 & 1,0 & 0,9 & 0,3 & 0,6 \\
\hline Cyfluthrin & PYR. & $0.003(\mathrm{a}, 2002)$ & $\mathrm{EU} / \mathrm{N}$ & 31,6 & 40,5 & 36,3 & 48,3 & 31,0 & 54,3 \\
\hline Cypermethrin & PYR. & $0.05(\mathrm{a}, 1994)$ & $\mathrm{EU} / \mathrm{N}$ & 9,9 & 15,1 & 13,7 & 17,4 & 9,4 & 17,4 \\
\hline Esfenvalerate & PYR. & $0.02(\mathrm{a}, 2000)$ & $\mathrm{EU} / \mathrm{N}$ & 1,6 & 2,0 & 2,1 & 2,3 & 2,0 & 2,7 \\
\hline Fenpropathrin & PYR. & $0.03(\mathrm{a},-)$ & $\mathrm{N}$ & 5,8 & 8,7 & 7,1 & 8,4 & 4,9 & 9,5 \\
\hline Fenvalerate & PYR. & $0.02(\mathrm{a},-)$ & $\mathrm{N}$ & 3,8 & 0,6 & 0,5 & 0,4 & 0,1 & 0,0 \\
\hline \multirow{2}{*}{$\begin{array}{c}\text { Flucythrinate } \\
\text { Fluvalinate }\end{array}$} & PYR. & $0.02(\mathrm{a},-)$ & $\mathrm{EU} / \mathrm{N}$ & 4,1 & 3,9 & 3,9 & 4,3 & 3,4 & 4,4 \\
\hline & PYR. & $0.01(\mathrm{c}, 1991)$ & & 0,0 & 0,0 & 0,0 & 0,0 & 0,0 & 0,0 \\
\hline $\begin{array}{l}\text { Lambda- } \\
\text { Cyhalothrin }\end{array}$ & PYR. & $0.005(\mathrm{a}, 2000)$ & $\mathrm{EU} / \mathrm{N}$ & 33,4 & 33,7 & 30,2 & 43,0 & 26,5 & 44,1 \\
\hline \multirow{2}{*}{$\begin{array}{l}\text { Permethrin } \\
\text { Resmethrin }\end{array}$} & PYR. & $0.05(\mathrm{a},-)$ & $\mathrm{EU} / \mathrm{N}$ & 2,6 & 1,6 & 1,6 & 1,7 & 1,4 & 1,8 \\
\hline & PYR. & $0.03(\mathrm{c}, 1988)$ & $\mathrm{EU} / \mathrm{N}$ & 5,1 & 5,0 & 4,9 & 5,5 & 4,2 & 5,6 \\
\hline \multirow{2}{*}{$\begin{array}{c}\text { Tau-Fluvalinate } \\
\text { Tefluthrin }\end{array}$} & PYR. & $0.01(\mathrm{a}, 1984)$ & $\mathrm{N}$ & 9,7 & 14,2 & 11,8 & 17,5 & 11,1 & 20,2 \\
\hline & PYR. & $0.013(\mathrm{a}, 2002)$ & $\mathrm{N}$ & 0,4 & 0,3 & 0,3 & 0,3 & 0,3 & 0,3 \\
\hline
\end{tabular}

\begin{tabular}{|c|c|c|c|c|c|c|c|c|c|}
\hline hrin & PYR. & $0.013(\mathrm{a}, 2002)$ & $\mathrm{N}$ & 0,4 & 0,3 & 0,3 & 0,3 & 0,3 & 0,3 \\
\hline $\begin{array}{c}\text { No ADI } \\
\text { available }\end{array}$ & PYR. & \multicolumn{8}{|c|}{ Tralomethrin } \\
\hline Ametryne & TRIAZ. & 0.009 (c, 1989) & $\mathrm{N}$ & 0,8 & 1,8 & 2,4 & 2,6 & 1,0 & 2,6 \\
\hline Anilazine & TRIAZ. & $0.1(\mathrm{a},-)$ & $\mathrm{N}$ & 2,2 & 1,8 & 2,0 & 1,7 & 1,7 & 1,6 \\
\hline Atrazine & TRIAZ. & $0.035(\mathrm{c}, 1993)$ & EU & 1,0 & 1,6 & 1,6 & 1,9 & 1,4 & 2,2 \\
\hline Cyromazine & TRIAZ. & $0.17(\mathrm{a}, 1984)$ & EU/N & 3,0 & 6,8 & 5,7 & 10,2 & 5,9 & 11,7 \\
\hline Prometryne & TRIAZ. & $0.004(\mathrm{c}, 1992)$ & $\mathrm{N}$ & 16,5 & 30,6 & 25,0 & 28,6 & 23,0 & 29,7 \\
\hline Pymetrozine & TRIAZ. & $0.03(\mathrm{a}, 2001)$ & $\mathrm{EU} / \mathrm{N}$ & 5,3 & 8,3 & 8,4 & 11,5 & 6,1 & 11,2 \\
\hline Simazine & TRIAZ. & $0.005(\mathrm{a}, 2003)$ & $\mathrm{N}$ & 5,6 & 9,8 & 5,0 & 8,3 & 3,2 & 17,2 \\
\hline \multicolumn{10}{|l|}{ Terbuthylazine } \\
\hline & TRIAZ. & $0.003(\mathrm{~d},-)$ & $\mathrm{N}$ & 6,4 & 8,1 & 6,7 & 6,9 & 5,1 & 9,5 \\
\hline Terbutryn & TRIAZ. & $0.001(\mathrm{c}, 1988)$ & $\mathrm{N}$ & 0,5 & 0,8 & 0,9 & 1,2 & 1,1 & 0,7 \\
\hline
\end{tabular}

\begin{tabular}{|c|c|c|c|c|c|c|c|c|c|}
\hline $\begin{array}{c}\text { No ADI } \\
\text { available }\end{array}$ & TRIAZ. & 年 & - & $\mathrm{Cy}$ & , Des & Terb & 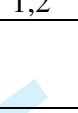 & 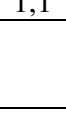 & , \\
\hline Amidosulfuron & UREA & $0.2(\mathrm{a}, 1995)$ & $\mathrm{N}$ & 0,1 & 0,1 & 0,1 & 0,1 & 0,1 & 0,1 \\
\hline Azimsulfuron & UREA & $0.1(\mathrm{a}, 1999)$ & EU & 0,2 & 0,3 & 0,3 & 0,3 & 0,3 & 0,4 \\
\hline $\begin{array}{l}\text { Bensulfuron- } \\
\text { methyl }\end{array}$ & UREA & $0.2(\mathrm{a}, 1990)$ & $\mathrm{N}$ & 0,0 & 0,0 & 0,0 & 0,0 & 0,1 & 0,0 \\
\hline Chloroxuron & UREA & $0.05(\mathrm{c}, 1990)$ & EU/N & 1,0 & 1,4 & 1,4 & 1,6 & 1,3 & 1,7 \\
\hline Chlortoluron & UREA & $0.04(\mathrm{a}, 2005)$ & $\mathrm{N}$ & 0,3 & 0,2 & 0,3 & 0,2 & 0,2 & 0,2 \\
\hline Cinosulfuron & UREA & $0.09(\mathrm{a}, 1993)$ & $\mathrm{N}$ & 0,0 & 0,0 & 0,0 & 0,0 & 0,1 & 0,0 \\
\hline Diflubenzuron & UREA & $0.02(\mathrm{a}, 1986)$ & $\mathrm{N}$ & 5,5 & 12,3 & 11,7 & 13,2 & 6,9 & 14,3 \\
\hline Diuron & UREA & $0.007(\mathrm{a}, 2005)$ & $\mathrm{N}$ & 1,7 & 2,8 & 2,3 & 2,3 & 1,7 & 3,4 \\
\hline Ethoxysulfuron & & & & & & & & & \\
\hline & UREA & $0.04(\mathrm{a}, 2003)$ & $\mathrm{EU} / \mathrm{N}$ & 1,2 & 1,7 & 1,7 & 2,0 & 1,7 & 2,2 \\
\hline Flazasulfuron & UREA & $0.013(\mathrm{a}, 2004)$ & $\mathrm{N}$ & 0,1 & 0,1 & 0,1 & 0,1 & 0,0 & 0,1 \\
\hline Flufenoxuron & UREA & $0.01(\mathrm{a}, 1999)$ & $\mathrm{N}$ & 9,2 & 11,9 & 9,8 & 10,0 & 7,0 & 13,7 \\
\hline
\end{tabular}


Flupyrsulfuronmethyl

Foramsulfuron

Hexaflumuron

Iodosulfuron-

methyl-sodium

Isoproturon

Linuron

Lufenuron

Methabenz-

thiazuron

Metsulfuronmethyl

Monolinuron

Nicosulfuron

Oxasulfuron

Pencycuron

Prosulfuron

Rimsulfuron

Sulfosulfuron

Teflubenzuron

Thifensulfuronmethyl

Triasulfuron

Triflumuron

Triflusulfuronmethyl

$$
\text { UREA }
$$

$\begin{array}{ccc}0.035(\mathrm{a}, 2001) & \mathrm{EU} & 0,6 \\ 0.5(\mathrm{a}, 2003) & \mathrm{EU} / \mathrm{N} & 0,0 \\ 0.005(\mathrm{a}, 1991) & \mathrm{N} & 12,2\end{array}$

0,8

0,8

0,9

0,8

1,1

$\begin{array}{lllll}\text { UREA } & 0.5(\mathrm{a}, 2003) & \mathrm{EU} / \mathrm{N} & 0,0 & 0,0\end{array}$

0,0

0,0

0,0

0,0

UREA

20,3

16,7

18,6

12,1

25,9

$$
\text { UREA } \quad 0.03(\mathrm{a}, 2003) \quad \text { EU } \quad 0,6
$$

$$
0,9
$$

$$
0,9
$$

1,0

0,8

1,2

UREA

0.015 (a, 2002)

EU/N 5,5

5,3

5,4

5,8

4,8

6,1

$$
\begin{aligned}
& \text { UREA } \\
& \text { UREA }
\end{aligned}
$$

$0.003(\mathrm{a}, 2003)$

EU/N

18,3

29,9

27,8

31,4

28,5

40,2

UREA

$0.004(\mathrm{~d},-) \quad \mathrm{N}$

5,6

4,5

5,1

14,5

8,5

17,7

$$
\text { URE }
$$

UREA

$0.22(\mathrm{a}, 2000)$

EU $\quad 0,2$

0,3

0,3

4,2

4,3

3,9

UREA

$0.003(\mathrm{a},-) \quad$ EU/N $\quad 27,3$

26,1

26,2

0,4

0,3

0,4

UREA $0.4(\mathrm{a}, 1994) \quad \mathrm{N} \quad 0,0$

0,0

0,0

28,5

22,8

29,2

\section{UREA}

$0.013(\mathrm{a}, 2003)$

EU/N

4,1

5,2

5,3

0,0

0,0

0,0

\section{UREA}

$0.025(\mathrm{a}, 1995) \quad \mathrm{N}$

1,8

4,8

4,4

6,0

5,1

6,7

UREA

0.02 (a, 2002)

EU

1,1

1,5

1,6

7,7

5,1

12,2

\section{UREA}

$0.1(\mathrm{a}, 2005)$

$\mathrm{N}$

0,0

0,0

0,0

1,8

2,1

UREA

$0.24(\mathrm{a}, 2002) \quad \mathrm{EU} / \mathrm{N}$

0,3

0,3

0,3

0,0

1,8

0,0

2,9

2,3

0,4

0,0

0,4

2,6

1,7

3,6

\section{UREA $\quad 0.01(\mathrm{a}, 2001)$}

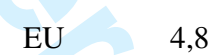

6,8

6,9

7,8

6,6

8,7

UREA $\quad 0.01(\mathrm{a}, 2000)$

EU $\quad 4,8$

6,8

6,9

7,8

6,6

8,7

UREA

0.005 (a, 1985)

23,8

39,9

32,5

36,4

23,9

50,7

UREA $0.04(\mathrm{a}, 1996)$

0,0

0,0

0,0

0,0

0,0

0,0

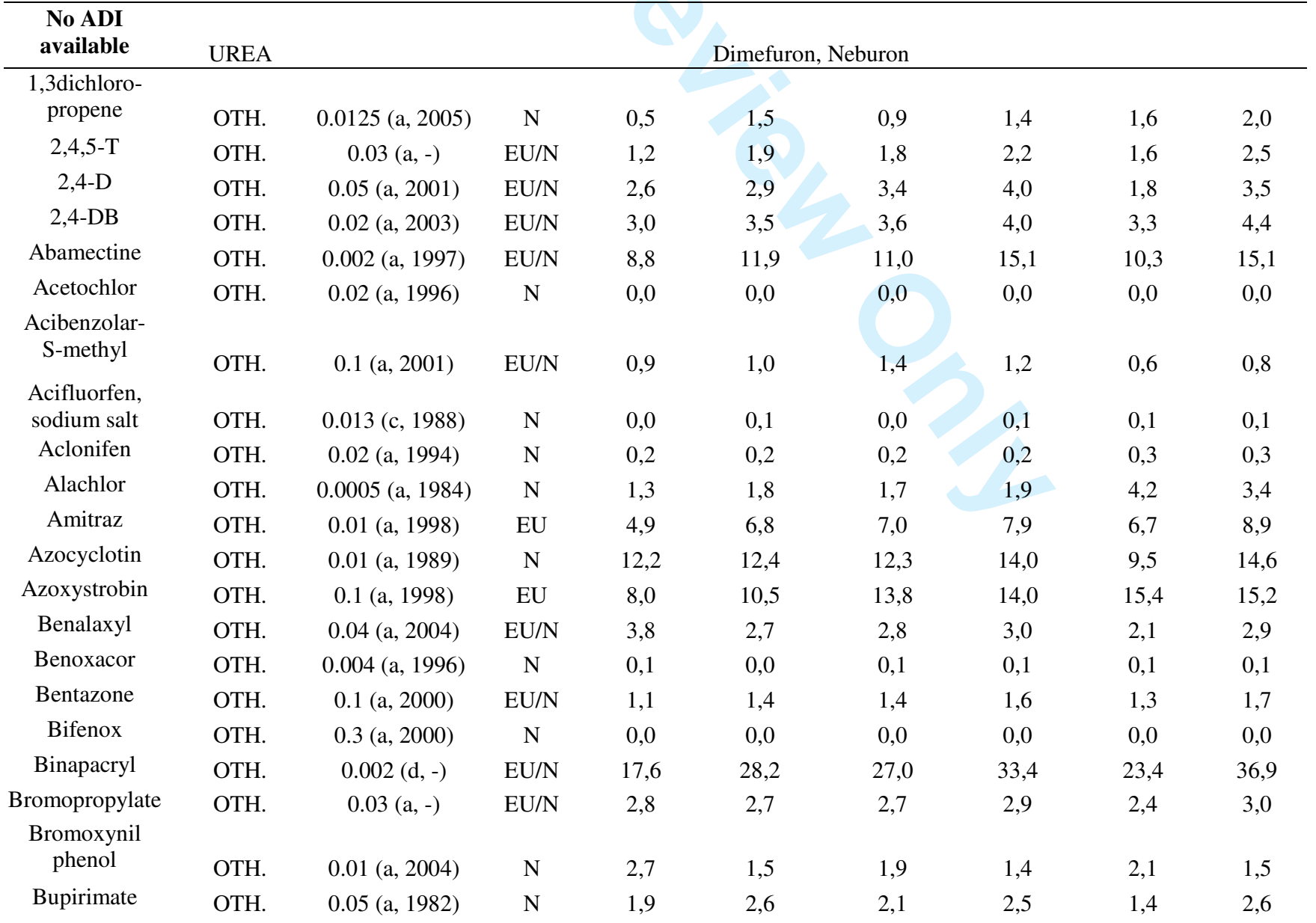




\begin{tabular}{|c|c|c|c|c|c|c|c|c|c|}
\hline Buprofezin & OTH. & $0.01(\mathrm{a}, 1990)$ & $\mathrm{N}$ & 1,2 & 1,6 & 2,9 & 2,3 & 0,7 & 1,6 \\
\hline Butralin & OTH. & $0.003(\mathrm{a}, 2005)$ & $\mathrm{N}$ & 0,8 & 0,6 & 0,7 & 0,5 & 0,2 & 0,5 \\
\hline Captan & OTH. & $0.1(\mathrm{a}, 2006)$ & $\mathrm{EU} / \mathrm{N}$ & 13,6 & 15,7 & 13,0 & 16,4 & 8,5 & 15,2 \\
\hline Captofol & OTH. & $0.002(\mathrm{c}, 1987)$ & EU/N & 13,7 & 16,9 & 18,6 & 19,1 & 19,1 & 21,5 \\
\hline Carbetamide & OTH. & $0.021(\mathrm{a}, 2005)$ & $\mathrm{N}$ & 0,1 & 0,2 & 0,1 & 0,1 & 0,0 & 0,0 \\
\hline $\begin{array}{c}\text { Carbon disulfide } \\
\text { Carbon }\end{array}$ & OTH. & $0.1(\mathrm{c}, 1990)$ & EU & 0,3 & 0,2 & 0,3 & 0,2 & 0,4 & 0,3 \\
\hline tetrachloride & ОТН. & $0.0007(\mathrm{c}, 1991)$ & EU & 37,9 & 32,1 & 44,4 & 32,5 & 55,6 & 38,5 \\
\hline \multicolumn{10}{|l|}{$\begin{array}{l}\text { Chinomethionat } \\
\text { (oxythioquinox) }\end{array}$} \\
\hline Chlorbenside & OTH. & $0.01(b, 1965)$ & EU/N & 4,3 & 2,4 & 2,3 & 2,3 & 1,5 & 1,8 \\
\hline Chlorfenson & OTH. & $0.01(\mathrm{a},-)$ & $\mathrm{EU} / \mathrm{N}$ & 1,0 & 1,3 & 1,4 & 1,5 & 1,3 & 1,7 \\
\hline Chlormequat & OTH. & 0.05 (a, 1997) & $\mathrm{EU} / \mathrm{N}$ & 11,7 & 11,2 & 11,0 & 12,0 & 9,6 & 9,9 \\
\hline Chlorobenzilate & OTH. & $0.02(\mathrm{a},-)$ & EU/N & 1,0 & 1,4 & 1,4 & 1,6 & 1,3 & 1,7 \\
\hline Chlozolinate & OTH. & $0.1(\mathrm{a},-)$ & EU & 0,5 & 0,7 & 0,7 & 0,8 & 0,7 & 0,9 \\
\hline Cinidon-ethyl & ОТН. & $0.01(\mathrm{a}, 2002)$ & EU & 6,3 & 8,1 & 8,7 & 9,2 & 9,0 & 10,4 \\
\hline Clethodim & OTH. & $0.01(\mathrm{a}, 1995)$ & $\mathrm{N}$ & 1,6 & 2,5 & 3,2 & 3,0 & 3,6 & 4,6 \\
\hline \multicolumn{9}{|l|}{ Clodinafop- } & 2,4 \\
\hline Clofentezine & OTH. & $0.02(\mathrm{a}, 1986)$ & EU/N & 12,1 & 14,3 & 11,6 & 16,3 & 6,9 & 13,4 \\
\hline Clomazone & OTH. & $0.043(\mathrm{a}, 2001)$ & $\mathrm{N}$ & 0,0 & 0,0 & 0,0 & 0,0 & 0,0 & 0,0 \\
\hline Clopyralid & OTH. & $0.15(\mathrm{a}, 2005)$ & $\mathrm{N}$ & 1,5 & 1,3 & 1,4 & 1,2 & 1,2 & 1,1 \\
\hline \multicolumn{10}{|l|}{ Cloquintocet- } \\
\hline & OTH. & $0.04(\mathrm{a}, 1993)$ & $\mathrm{N}$ & 0,3 & 0,2 & 0,2 & 0,2 & 0,2 & 0,2 \\
\hline Copper & OTH. & $0.5(\mathrm{a},-)$ & $\mathrm{N}$ & 3,9 & 3,3 & 2,9 & 2,4 & 1,2 & 2,2 \\
\hline Cyclanilide & OTH. & $0.0075(\mathrm{a}, 2001)$ & $\mathrm{EU} / \mathrm{N}$ & 7,3 & 9,3 & 9,5 & 10,6 & 8,9 & 11,6 \\
\hline Cycloxydim & OTH. & $0.07(\mathrm{a}, 2004)$ & $\mathrm{N}$ & 2,8 & 4,2 & 4,1 & 3,8 & 3,1 & 5,0 \\
\hline Cyhalofop-butyl & ОТН. & $0.003(\mathrm{a}, 2002)$ & EU & 6,7 & 9,4 & 9,6 & 10,9 & 9,7 & 12,3 \\
\hline Cymoxanil & OTH. & $0.016(\mathrm{a}, 1999)$ & $\mathrm{N}$ & 1,2 & 1,2 & 1,4 & 1,2 & 0,5 & 1,2 \\
\hline Cyprodinyl & OTH. & $0.03(\mathrm{a}, 2003)$ & $\mathrm{N}$ & 15,5 & 27,2 & 21,8 & 37,9 & 24,8 & 46,1 \\
\hline Daminozide & OTH. & $0.45(\mathrm{a}, 2005)$ & $\mathrm{EU} / \mathrm{N}$ & 0,1 & 0,1 & 0,1 & 0,1 & 0,1 & 0,1 \\
\hline Dicamba & OTH. & $0.02(\mathrm{a}, 1995)$ & $\mathrm{N}$ & 0,0 & 0,0 & 0,0 & 0,0 & 0,0 & 0,0 \\
\hline Dichlobenil & OTH. & $0.01(\mathrm{a}, 1997)$ & $\mathrm{N}$ & 0,6 & 0,5 & 0,5 & 0,4 & 0,1 & 0,3 \\
\hline Dichlofluanid & OTH. & $0.3(\mathrm{a},-)$ & EU/N & 11,9 & 19,3 & 17,0 & 23,0 & 15,0 & 24,0 \\
\hline Dichlorprop & OTH. & $0.03(\mathrm{~d},-)$ & EU/N & 1,6 & 2,3 & 2,3 & 2,6 & 2,2 & 2,9 \\
\hline Dichlorprop-P & OTH. & $0.06(\mathrm{a}, 2006)$ & EU & 0,6 & 0,9 & 0,9 & 1,1 & 0,8 & 1,2 \\
\hline Diclobutrazol & OTH. & $0.03(\mathrm{~d},-)$ & $\mathrm{N}$ & 2,4 & 1,8 & 1,9 & 1,5 & 0,7 & 1,3 \\
\hline Diclofop-methyl & OTH. & $0.001(\mathrm{a}, 2005)$ & $\mathrm{N}$ & 27,8 & 39,5 & 35,1 & 37,5 & 31,5 & 37,4 \\
\hline Diflufenican & OTH. & $0.25(\mathrm{a}, 2000)$ & $\mathrm{N}$ & 0,0 & 0,0 & 0,0 & 0,0 & 0,0 & 0,0 \\
\hline Dimethachlore & OTH. & $0.11(\mathrm{a}, 1999)$ & $\mathrm{N}$ & 0,0 & 0,0 & 0,0 & 0,0 & 0,0 & 0,0 \\
\hline Dimethenamid & OTH. & $0.02(\mathrm{a}, 2005)$ & $\mathrm{N}$ & 0,0 & 0,0 & 0,0 & 0,0 & 0,0 & 0,0 \\
\hline Dimethenamid- & & & & & & & & & \\
\hline $\mathrm{P}$ & OTH. & $0.02(\mathrm{a}, 2003)$ & EU & 0,0 & 0,0 & 0,0 & 0,0 & 0,0 & 0,0 \\
\hline Dimethipin & ОТН. & 0.02 (a, 1999) & $\mathrm{N}$ & 0,4 & 0,4 & 0,7 & 0,5 & 0,3 & 0,4 \\
\hline Dimethomorph & OTH. & $0.05(\mathrm{a}, 2006)$ & $\mathrm{N}$ & 4,9 & 3,6 & 3,8 & 2,9 & 1,0 & 2,6 \\
\hline Dinocap & OTH. & $0.004(\mathrm{a}, 2004)$ & EU/N & 9,0 & 15,5 & 14,0 & 18,8 & 9,0 & 19,8 \\
\hline Dinoseb & OTH. & 0.003 (c, 1989) & EU/N & 11,7 & 18,8 & 18,0 & 22,3 & 15,6 & 24,6 \\
\hline Diphenylamine & OTH. & $0.08(\mathrm{a}, 1998)$ & EU & 7,0 & 13,6 & 10,3 & 14,0 & 8,2 & 18,4 \\
\hline Dithianon & ОТН. & $0.01(\mathrm{a}, 1992)$ & $\mathrm{N}$ & 10,4 & 21,3 & 17,3 & 18,8 & 12,2 & 25,4 \\
\hline Dodine & OTH. & $0.1(\mathrm{a}, 2000)$ & EU/N & 2,1 & 3,8 & 3,3 & 4,1 & 2,7 & 4,6 \\
\hline Ethofumesate & OTH. & $0.07(\mathrm{a}, 2002)$ & EU/N & 1,7 & 1,3 & 1,3 & 1,4 & 1,1 & 1,3 \\
\hline
\end{tabular}




\begin{tabular}{|c|c|c|c|c|c|c|c|c|c|}
\hline $\begin{array}{l}\text { Ethylene } \\
\text { dibromide }\end{array}$ & ОТН. & $0.009(\mathrm{c}, 2004)$ & EU & 1,1 & 1,5 & 1,6 & 1,7 & 1,5 & 1,9 \\
\hline Etofenprox & OTH. & $0.03(\mathrm{a}, 1995)$ & $\mathrm{N}$ & 0,7 & 0,5 & 1,5 & 2,5 & 0,8 & 2,9 \\
\hline Famoxadone & OTH. & $0.012(\mathrm{a}, 1995)$ & $\mathrm{EU} / \mathrm{N}$ & 20,6 & 15,0 & 14,0 & 15,3 & 8,3 & 13,1 \\
\hline Fenamidone & OTH. & $0.03(\mathrm{a}, 2003)$ & $\mathrm{EU} / \mathrm{N}$ & 3,9 & 6,3 & 6,1 & 9,0 & 5,3 & 9,9 \\
\hline Fenarimol & OTH. & $0.01(\mathrm{a}, 1995)$ & $\mathrm{EU} / \mathrm{N}$ & 12,6 & 17,2 & 17,8 & 18,6 & 9,2 & 16,7 \\
\hline Fenazaquin & OTH. & $0.005(a, 1993)$ & $\mathrm{N}$ & 11,9 & 16,0 & 18,8 & 16,3 & 6,3 & 11,7 \\
\hline Fenbutatin oxide & OTH. & $0.025(\mathrm{a}, 1973)$ & $\mathrm{EU} / \mathrm{N}$ & 35,9 & 45,3 & 49,6 & 59,8 & 21,2 & 54,7 \\
\hline Fenchlorim & OTH. & $0.05(\mathrm{a}, 1988)$ & $\mathrm{N}$ & 0,1 & 0,1 & 0,1 & 0,1 & 0,2 & 0,1 \\
\hline Fenhexamid & OTH. & $0.2(a, 2000)$ & $\mathrm{EU} / \mathrm{N}$ & 6,6 & 12,9 & 10,4 & 19,3 & 10,2 & 20,7 \\
\hline $\begin{array}{c}\text { Fenoxaprop } \\
\text { ethyl }\end{array}$ & OTH. & $0.01(\mathrm{a}, 1988)$ & $\mathrm{N}$ & 1,1 & 0,9 & 1,0 & 0,8 & 0,9 & 0,8 \\
\hline Fenpropidine & OTH. & $0.005(\mathrm{a}, 1995)$ & $\mathrm{N}$ & 4,5 & 3,6 & 4,1 & 3,3 & 3,5 & 3,1 \\
\hline Fenpyroximate & OTH. & $0.01(\mathrm{a}, 1999)$ & $\mathrm{N}$ & 2,3 & 3,8 & 3,3 & 3,0 & 2,3 & 4,5 \\
\hline Florasulam & OTH. & $0.05(\mathrm{a}, 2002)$ & EU & 0,3 & 0,4 & 0,4 & 0,4 & 0,4 & 0,5 \\
\hline Fluazifop-P- & & & & & & & & & \\
\hline & OTH. & $0.01(\mathrm{a}, 2001)$ & $\mathrm{N}$ & 6,3 & 21,6 & 22,0 & 28,4 & 61,1 & 47,1 \\
\hline Fluazinam & OTH. & $0.01(\mathrm{a}, 1997)$ & $\mathrm{N}$ & 36,5 & 27,1 & 28,2 & 21,8 & 7,9 & 19,2 \\
\hline Fludioxonil & OTH. & $0.03(\mathrm{a}, 2003)$ & $\mathrm{N}$ & 10,3 & 22,9 & 20,6 & 34,9 & 22,3 & 52,4 \\
\hline Flufenacet & OTH. & $0.005(\mathrm{a}, 2003)$ & EU & 10,6 & 14,4 & 15,1 & 16,7 & 13,8 & 19,3 \\
\hline Flumioxazine & OTH. & $0.009(a, 2002)$ & EU & 5,5 & 7,7 & 7,9 & 8,9 & 7,8 & 10,1 \\
\hline Fluroxypyr & OTH. & $0.8(\mathrm{a}, 2000)$ & $\mathrm{EU}$ & 0,1 & 0,1 & 0,1 & 0,1 & 0,1 & 0,1 \\
\hline Flutolanil & OTH. & $0.01(\mathrm{a}, 1992)$ & $\mathrm{N}$ & 0,8 & 0,7 & 1,1 & 0,9 & 0,4 & 1,4 \\
\hline Folpet & OTH. & $0.1(\mathrm{a}, 2006)$ & $\mathrm{EU} / \mathrm{N}$ & 14,0 & 16,2 & 13,6 & 17,0 & 9,9 & 15,8 \\
\hline Fomesafen & OTH. & $0.01(\mathrm{a},-)$ & $\mathrm{N}$ & 0,3 & 0,4 & 0,3 & 0,3 & 0,4 & 0,1 \\
\hline Fosetyl-Al & OTH. & $3(\mathrm{a}, 2005)$ & $\mathrm{N}$ & 0,4 & 0,5 & 0,4 & 0,6 & 0,3 & 0,5 \\
\hline Glufosinate & OTH. & $0.02(a, 2005)$ & $\mathrm{N}$ & 12,2 & 18,9 & 17,2 & 20,8 & 14,3 & 24,4 \\
\hline Glyphosate & OTH. & $0.3(\mathrm{a}, 2001)$ & $\mathrm{EU} / \mathrm{N}$ & 5,6 & 5,7 & 6,8 & 7,0 & 10,3 & 7,5 \\
\hline $\begin{array}{l}\text { Haloxyfop- } \\
\text { Ethoxyethyl }\end{array}$ & OTH. & $0.0007(\mathrm{a},-)$ & $\mathrm{N}$ & 3,8 & 2,9 & 2,7 & 3,2 & 1,8 & 1,8 \\
\hline Haloxyfop-R- & & & & & & & & & \\
\hline nethyl & OTH. & $0.0007(\mathrm{a}, 1991)$ & $\mathrm{N}$ & 4,6 & 7,6 & 6,4 & 7,8 & 12,5 & 10,0 \\
\hline Hexythiazox & ОТН. & $0.03(\mathrm{a}, 1988)$ & $\mathrm{N}$ & 5,8 & 8,6 & 7,5 & 9,2 & 6,6 & 10,1 \\
\hline $\begin{array}{l}\text { Hydrogen } \\
\text { phosphide }\end{array}$ & OTH. & $0.0003(\mathrm{c}, 1993)$ & EU & 88,5 & 74,8 & 103,6 & 75,8 & 129,7 & 89,9 \\
\hline mazamethabenz & OTH. & $0.06(\mathrm{a}, 2004)$ & $\mathrm{N}$ & 0,2 & 0,2 & 0,2 & 0,2 & 0,2 & 0,1 \\
\hline Imazamox & OTH. & $9(\mathrm{a}, 2002)$ & $\mathrm{EU} / \mathrm{N}$ & & 0,0 & 0,0 & 0,0 & 0,0 & 0,0 \\
\hline Imazaquin & OTH. & $0.25(\mathrm{c}, 1990)$ & $\mathrm{N}$ & 0,0 & 0,0 & 0,0 & 0,0 & 0,0 & 0,0 \\
\hline Imidacloprid & OTH. & $0.05(\mathrm{a}, 1991)$ & $\mathrm{N}$ & 1,3 & 1,7 & 1,5 & 1,6 & 1,2 & 1,9 \\
\hline Ioxynil & OTH. & $0.005(a, 2004)$ & $\mathrm{N}$ & 5,2 & 2,7 & 3,5 & 2,6 & 4,0 & 2,7 \\
\hline Iprodione & ОТН. & $0.06(\mathrm{a}, 2003)$ & $\mathrm{EU} / \mathrm{N}$ & 41,1 & 59,0 & 54,8 & 70,2 & 42,3 & 67,8 \\
\hline Isoxaben & OTH. & $0.05(\mathrm{a}, 1995)$ & $\mathrm{N}$ & 0,1 & 0,2 & 0,1 & 0,2 & 0,1 & 0,2 \\
\hline Isoxaflutole & OTH. & $0.02(\mathrm{a}, 2003)$ & EU & 2,5 & 3,5 & 3,5 & 4,0 & 3,5 & 4,6 \\
\hline $\begin{array}{c}\text { Kresoxim- } \\
\text { methyl }\end{array}$ & ОТН. & 0.4 (a, 1999) & EU & 0,5 & 0,6 & 0,5 & 0,6 & 0,3 & 0,5 \\
\hline Maleic & & & & & & & & & \\
\hline hydrazide & Отн. & $0.25(\mathrm{a},-)$ & EU & 17,5 & 17,1 & 24,2 & 20,3 & 12,0 & 31,7 \\
\hline Mecoprop & ОТН. & $0.01(\mathrm{a}, 2003)$ & EU & 4,9 & 6,8 & 7,0 & 7,9 & 6,7 & 9,0 \\
\hline Mecoprop-p & OTH. & $0.01(\mathrm{a}, 2003)$ & $\mathrm{EU}$ & 4,9 & 6,8 & 7,0 & 7,9 & 6,7 & 9,0 \\
\hline Mepiquat & OTH. & $0.58(\mathrm{a}, 2004)$ & $\mathrm{N}$ & 0,6 & 0,5 & 0,5 & 0,5 & 0,4 & 0,3 \\
\hline Mesotrione & OTH. & $0.01(\mathrm{a}, 2003)$ & EU & 4,9 & 6,8 & 7,0 & 7,9 & 6,7 & 9,0 \\
\hline Metalaxyl & OTH. & $0.03(\mathrm{a},-)$ & $\mathrm{EU} / \mathrm{N}$ & 8,9 & 11,8 & 10,9 & 12,4 & 8,0 & 14,6 \\
\hline Metalaxyl-M & OTH. & $0.08(\mathrm{a}, 2002)$ & $\mathrm{EU} / \mathrm{N}$ & 3,6 & 5,2 & 4,8 & 5,9 & 3,3 & 6,5 \\
\hline
\end{tabular}




\begin{tabular}{|c|c|c|c|c|c|c|c|c|c|}
\hline Metamitron & ОТн. & $0.025(\mathrm{a}, 2003)$ & $\mathrm{N}$ & 0,0 & 0,1 & 0,1 & 0,1 & 0,0 & 0,0 \\
\hline Metazachlor & ОТН. & $0.036(\mathrm{a},-)$ & $\mathrm{N}$ & 0,0 & 0,0 & 0,1 & 0,1 & 0,1 & 0,1 \\
\hline $\begin{array}{l}\text { Methoprene } \\
\text { (Methrprene) }\end{array}$ & OTH. & $0.4(\mathrm{~d},-)$ & $\mathrm{N}$ & 0,0 & 0,0 & 0,1 & 0,1 & 0,0 & 0,0 \\
\hline Methyl bromide & OTH. & $0.1(\mathrm{a}, 1966)$ & $\mathrm{EU} / \mathrm{N}$ & 0,6 & 0,8 & 0,9 & 0,9 & 0,9 & 1,0 \\
\hline Metolachlor & OTH. & $0.15(\mathrm{c}, 1994)$ & $\mathrm{N}$ & 0,1 & 0,1 & 0,1 & 0,1 & 0,0 & 0,1 \\
\hline Metosulam & OTH. & $0.005(\mathrm{a}, 2006)$ & $\mathrm{N}$ & 0,9 & 0,7 & 0,9 & 0,7 & 0,8 & 0,7 \\
\hline Metribuzine & OTH. & $0.013(\mathrm{a}, 1999)$ & $\mathrm{N}$ & 1,9 & 2,0 & 2,6 & 2,1 & 1,5 & 2,4 \\
\hline Napropamide & ОTH. & $0.125(\mathrm{a}, 1999)$ & $\mathrm{N}$ & 0,1 & 0,2 & 0,2 & 0,2 & 0,1 & 0,2 \\
\hline $\begin{array}{l}\text { Nitrothal- } \\
\text { isopropyl }\end{array}$ & OTH. & $0.05(\mathrm{~d},-)$ & $\mathrm{N}$ & 2,4 & 4,0 & 3,2 & 3,6 & 2,4 & 5,1 \\
\hline Norflurazon & ОTH. & $0.04(c, 1991)$ & $\mathrm{N}$ & 0,2 & 0,4 & 0,4 & 0,4 & 0,5 & 0,6 \\
\hline $\begin{array}{c}\text { Ortho- } \\
\text { phenylphenol }\end{array}$ & OTH. & $0.4(\mathrm{~d},-)$ & $\mathrm{N}$ & 3,0 & 2,9 & 3,7 & 5,0 & 1,2 & 3,4 \\
\hline Oryzalin & OTH. & $0.05(c, 1991)$ & $\mathrm{N}$ & 0,1 & 0,1 & 0,1 & 0,2 & 0,1 & 0,2 \\
\hline Oxadiargyl & OTH. & $0.008(\mathrm{a}, 2003)$ & $\mathrm{EU} / \mathrm{N}$ & 1,2 & 1,7 & 1,7 & 2,0 & 1,7 & 2,2 \\
\hline Oxadiazon & ОTH. & $0.004(\mathrm{a}, 2004)$ & $\mathrm{EU} / \mathrm{N}$ & 4,2 & 6,6 & 6,2 & 8,0 & 4,0 & 8,5 \\
\hline Oxadixyl & OTH. & $0.01(\mathrm{~d},-)$ & $\mathrm{N}$ & 16,4 & 16,9 & 18,2 & 17,9 & 6,7 & 13,1 \\
\hline Oxyfluorfen & ОТН. & $0.004(\mathrm{a}, 1997)$ & $\mathrm{N}$ & 0,7 & 0,6 & 0,6 & 0,5 & 0,2 & 0,3 \\
\hline Paraquat & ОTH. & $0.004(\mathrm{a}, 2003)$ & EU & 3,6 & 5,7 & 5,5 & 6,8 & 4,7 & 7,6 \\
\hline Pendimethalin & OTH. & $0.125(\mathrm{a}, 2003)$ & $\mathrm{EU} / \mathrm{N}$ & 0,7 & 0,8 & 0,8 & 0,8 & 0,7 & 0,9 \\
\hline Picloram & OTH. & $0.2(a, 2003)$ & $\mathrm{N}$ & 0,0 & 0,0 & 0,0 & 0,0 & 0,0 & 0,0 \\
\hline Picolinafen & OTH. & $0.014(\mathrm{a}, 2002)$ & $\mathrm{EU}$ & 3,5 & 5,0 & 5,1 & 5,7 & 5,0 & 6,5 \\
\hline Picoxystrobin & ОТН. & $0.043(\mathrm{a}, 2003)$ & EU & 1,5 & 1,7 & 1,7 & 1,9 & 1,7 & 2,1 \\
\hline $\begin{array}{l}\text { Piperonyl } \\
\text { butoxide }\end{array}$ & OTH. & $0.2(\mathrm{a}, 2001)$ & $\mathrm{N}$ & 13,2 & 11,2 & 15,5 & 11,3 & 19,4 & 13,4 \\
\hline Pretilachlor & ОТН. & $0.018(\mathrm{a}, 1988)$ & $\mathrm{N}$ & 0,1 & 0,2 & 0,3 & 0,2 & 0,6 & 0,3 \\
\hline Procymidone & OTH. & $0.025(\mathrm{a}, 2003)$ & $\mathrm{EU} / \mathrm{N}$ & 35,6 & 46,6 & 40,1 & 61,6 & 27,4 & 45,8 \\
\hline Prohexadione & & & & & & & & & \\
\hline calcium & OTH. & $0.2(\mathrm{a}, 2000)$ & $\mathrm{EU} / \mathrm{N}$ & 0,5 & 0,5 & 0,5 & 0,5 & 0,5 & 0,6 \\
\hline Propachlor & OTH. & $0.013(\mathrm{c}, 1992)$ & $\mathrm{N}$ & 0,0 & 0,0 & 0,0 & 0,0 & 0,0 & 0,0 \\
\hline Propaquizafop & OTH. & $0.003(\mathrm{a}, 1995)$ & $\mathrm{N}$ & 1,6 & 1,8 & 2,5 & 2,5 & 1,5 & 2,7 \\
\hline Propargite & OTH. & $0.02(a, 1995)$ & $\mathrm{EU} / \mathrm{N}$ & 19,9 & 24,8 & 21,9 & 22,1 & 14,3 & 27,7 \\
\hline Propyzamide & ОTH. & $0.085(\mathrm{a}, 2003)$ & $\mathrm{EU} / \mathrm{N}$ & 0,6 & 1,0 & 0,9 & 1,5 & 1,0 & 1,8 \\
\hline Pyraclostrobin & ОTH. & $0.03(\mathrm{a}, 2004)$ & $\mathrm{EU} / \mathrm{N}$ & 11,6 & 14,2 & 12,7 & 18,7 & 10,3 & 19,6 \\
\hline Pyraflufen-ethyl & OTH. & $0.2(\mathrm{a}, 2001)$ & $\mathrm{EU}$ & 0,1 & 0,1 & 0,1 & 0,2 & 0,2 & 0,2 \\
\hline Pyrethrins & ОTH. & $0.04(\mathrm{a},-)$ & $\mathrm{EU} / \mathrm{N}$ & 34,8 & 42,2 & 46,4 & 47,0 & 49,5 & 52,1 \\
\hline Pyridabene & OTH. & 0.008 (a, 1990) & $\mathrm{N}$ & 2,5 & 3,2 & 2,7 & 2,7 & 1,9 & 3,5 \\
\hline Pyridate & ОТН. & $0.036(\mathrm{a}, 2001)$ & $\mathrm{EU} / \mathrm{N}$ & 2,6 & 2,7 & 2,6 & 2,8 & 2,5 & 2,8 \\
\hline Pyrifenox & OTH. & $0.007(\mathrm{~d},-)$ & $\mathrm{N}$ & 2,1 & 3,0 & 2,7 & 2,7 & 1,9 & 3,6 \\
\hline Pyrimethanil & OTH. & $0.17(\mathrm{a}, 2006)$ & $\mathrm{N}$ & 1,7 & 2,2 & 2,0 & 2,6 & 1,4 & 2,6 \\
\hline Pyriproxyfen & OTH. & $0.07(\mathrm{a}, 1993)$ & $\mathrm{N}$ & 0,1 & 0,1 & 0,2 & 0,1 & 0,0 & 0,1 \\
\hline Quinclorac & ОТН. & $0.3(\mathrm{~d},-)$ & $\mathrm{N}$ & 0,0 & 0,0 & 0,0 & 0,0 & 0,0 & 0,0 \\
\hline Quinmerac & OTH. & 0.08 (a, 1993) & $\mathrm{N}$ & 0,1 & 0,1 & 0,1 & 0,1 & 0,1 & 0,1 \\
\hline Quinoxyfen & OTH. & $0.2(\mathrm{a}, 2004)$ & $\mathrm{N}$ & 0,8 & 0,5 & 0,5 & 0,4 & 0,2 & 0,3 \\
\hline Quintozene & ОTH. & $0.1(\mathrm{a},-)$ & $\mathrm{EU} / \mathrm{N}$ & 0,3 & 0,3 & 0,3 & 0,3 & 0,3 & 0,4 \\
\hline Quizalofop- & & & & & & & & & \\
\hline Ethyl & OTH. & $0.009(\mathrm{a},-)$ & $\mathrm{N}$ & 2,8 & 4,5 & 4,1 & 4,8 & 3,6 & 5,7 \\
\hline Sethoxydim & OTH. & $0.09(\mathrm{c}, 1989)$ & $\mathrm{N}$ & 3,8 & 6,1 & 5,8 & 7,2 & 4,8 & 7,9 \\
\hline Silthiopham & ОTH. & $0.064(\mathrm{a}, 2003)$ & EU & 0,8 & 1,1 & 1,1 & 1,2 & 1,0 & 1,4 \\
\hline Spiroxamine & ОTH. & $0.025(\mathrm{a}, 1999)$ & $\mathrm{EU} / \mathrm{N}$ & 5,7 & 5,0 & 4,6 & 5,4 & 3,8 & 5,5 \\
\hline Sulfosate & OTH. & $0.2(\mathrm{a}, 2001)$ & $\mathrm{N}$ & 5,9 & 4,8 & 6,0 & 5,0 & 6,2 & 5,0 \\
\hline Tebufenozide & OTH. & $0.02(\mathrm{a}, 1993)$ & $\mathrm{N}$ & 7,6 & 8,4 & 7,3 & 8,0 & 6,5 & 10,0 \\
\hline
\end{tabular}




$\begin{array}{cccccccccc}\text { Tecnazene } & \text { OTH. } & 0.02(\mathrm{a},-) & \mathrm{EU} / \mathrm{N} & 4,1 & 3,9 & 3,9 & 4,3 & 3,4 & 4,4 \\ \text { Tetradifon } & \text { OTH. } & 0.0075(\mathrm{a},-) & \mathrm{N} & 58,2 & 74,5 & 62,4 & 70,8 & 42,0 & 81,9 \\ \text { Tolylfluanide } & \text { OTH. } & 0.1(\mathrm{a}, 2005) & \mathrm{N} & 2,4 & 4,0 & 3,2 & 3,6 & 2,4 & 5,1 \\ \text { Tralkoxydime } & \text { OTH. } & 0.005(\mathrm{a}, 1991) & \mathrm{N} & 0,9 & 0,7 & 0,8 & 0,7 & 0,6 & 0,6 \\ \text { Triclopyr } & \text { OTH. } & 0.03(\mathrm{a}, 2005) & \mathrm{N} & 1,7 & 1,9 & 4,0 & 2,5 & 7,6 & 4,0 \\ \text { Tridemorph } & \text { OTH. } & 0.01(\mathrm{a}, 2000) & \mathrm{EU} / \mathrm{N} & 8,4 & 8,1 & 8,2 & 9,0 & 7,7 & 9,3 \\ \text { Trifloxystrobin } & \text { OTH. } & 0.1(\mathrm{a}, 2003) & \mathrm{EU} & 5,6 & 5,2 & 4,5 & 5,1 & 2,5 & 4,7 \\ \text { Trifluralin } & \text { OTH. } & 0.015(\mathrm{a}, 2005) & \mathrm{N} & 0,4 & 0,9 & 0,7 & 0,8 & 0,8 & 1,0 \\ \text { Triforine } & \text { OTH. } & 0.02(\mathrm{a},-) & \mathrm{EU} / \mathrm{N} & 15,7 & 26,3 & 22,5 & 25,4 & 16,8 & 30,0\end{array}$

Trinexapac -

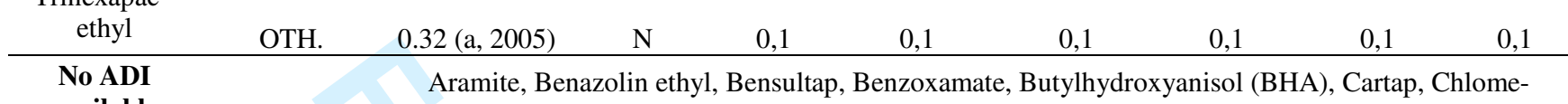
available thoxyfen, Difenzoquat, Diflufenicanil, Dinoterb, DNOC, Fentin compunds, Flubenzimine,

Flumequine, Fluorochloridone, Fluoroglycofen, Flupoxam, Hymexazol, Mefenoxam, Mepronil, Naphthalene acetic acid (NAA), Nitrofen, Nuarimol, Ortho-phenylphenol sodium salt, OTH. Phosametine, Sulcotrione, Sulfur, Tetrasul, Thiazopyr, Trimethylsulfonium. 